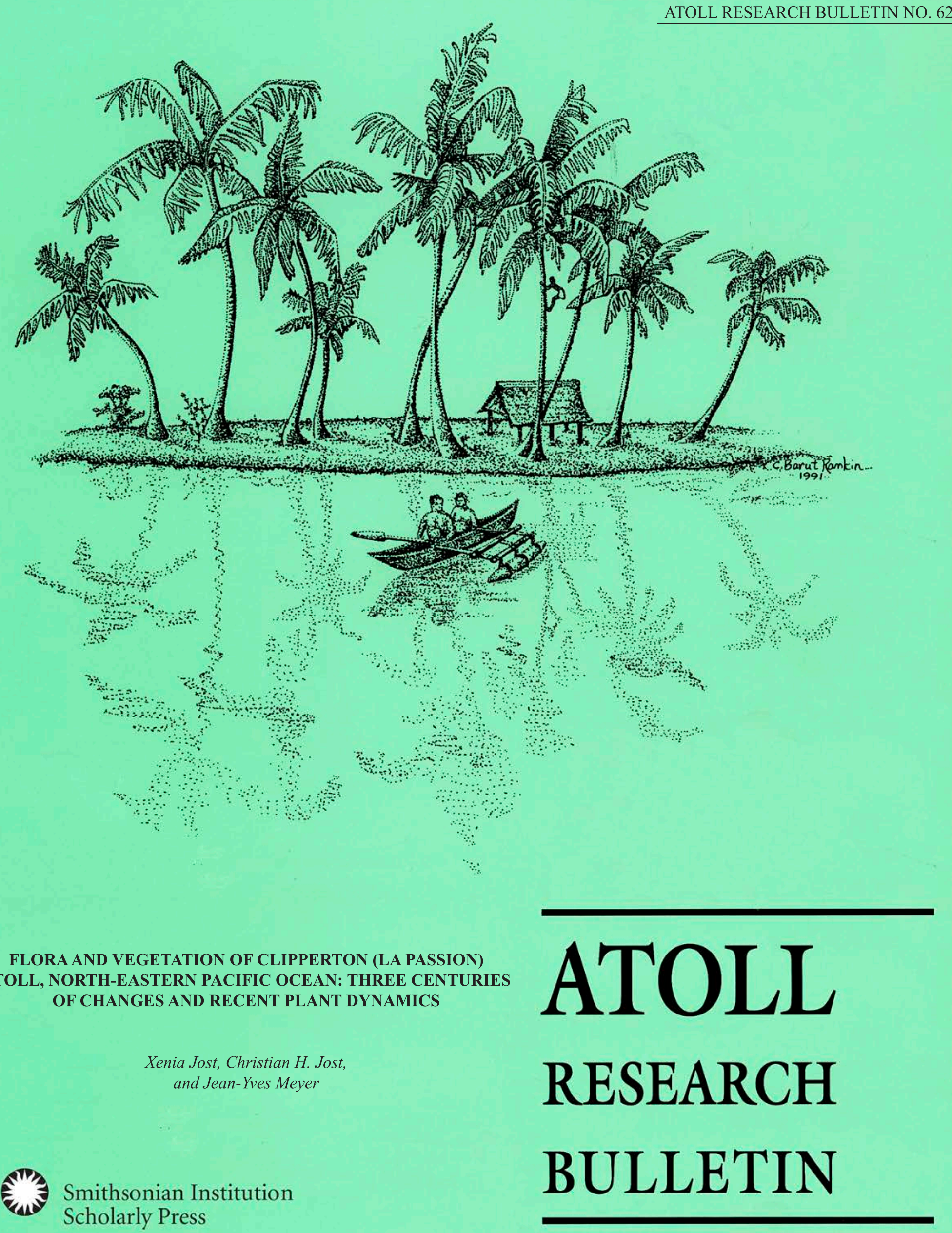




\section{FLORA AND VEGETATION OF CLIPPERTON (LA PASSION) ATOLL, NORTH-EASTERN PACIFIC OCEAN: THREE CENTURIES OF CHANGES AND RECENT PLANT DYNAMICS}

Xenia Jost, Christian H. Jost, and Jean-Yves Meyer

Atoll Research Bulletin No. 623 • 6 June 2019

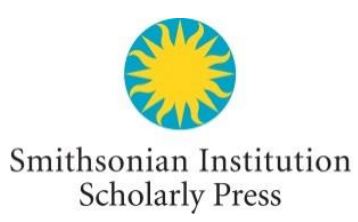

Washington, D.C. 
All statements made in papers published in the Atoll Research Bulletin are the sole responsibility of the authors and do not necessarily represent the views of the Smithsonian Institution or of the editors of the bulletin. Articles submitted for publication in the Atoll Research Bulletin should be original papers and must be made available by authors for open access publication. Manuscripts should be consistent with the "Author Formatting Guidelines for Publication in the Atoll Research Bulletin." All submissions to the bulletin are peer reviewed and, after revision, are evaluated prior to acceptance and publication through the publisher's open access portal, Open SI (https://opensi.si.edu).

\section{Published by SMITHSONIAN INSTITUTION SCHOLARLY PRESS}

P.O. Box 37012, MRC 957

Washington, D.C. 20013-7012

https://scholarlypress.si.edu/

The rights to all text and images in this publication are owned either by the contributing authors or by third parties. Fair use of materials is permitted for personal, educational, or noncommercial purposes. Users must cite author and source of content, must not alter or modify the content, and must comply with all other terms or restrictions that may be applicable. Users are responsible for securing permission from a rights holder for any other use.

ISSN: 0077-5630 (online) 


\section{CONTENTS}

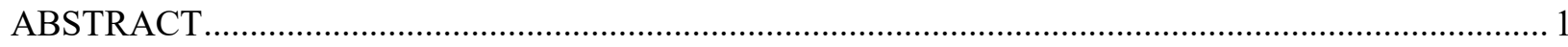

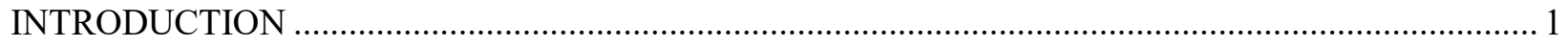

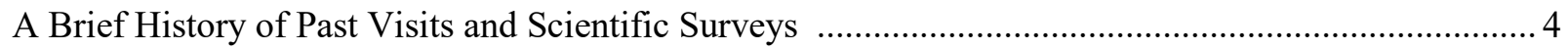

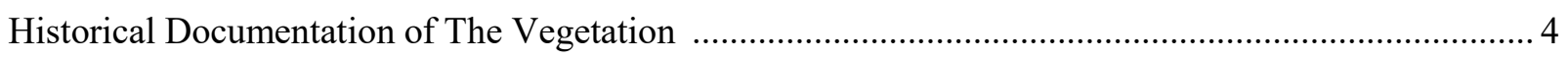

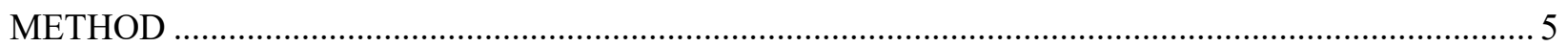

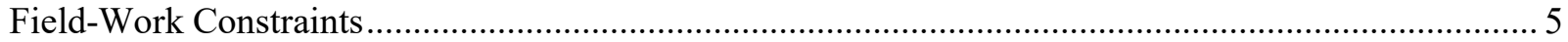

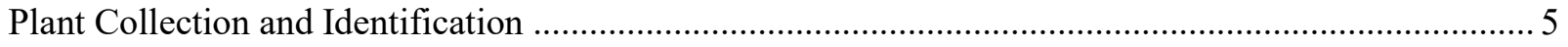

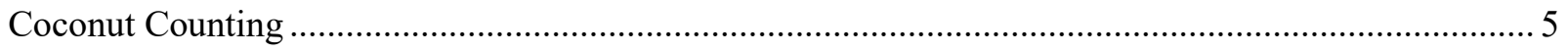

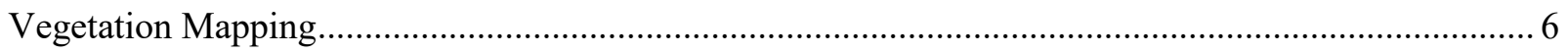

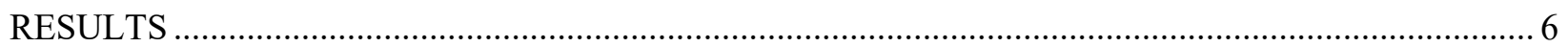

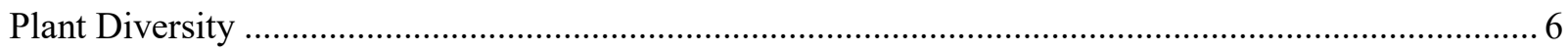

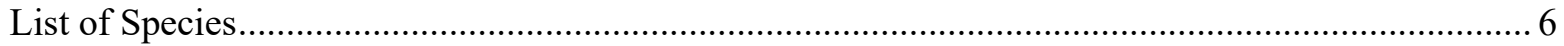

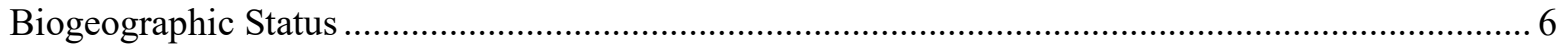

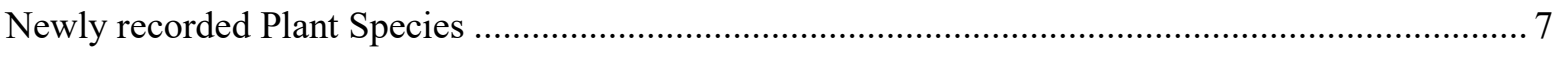

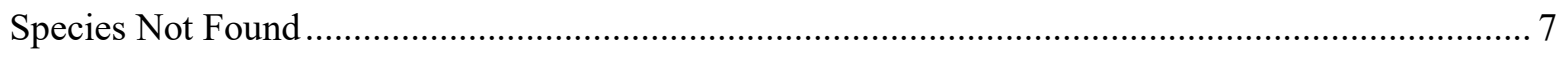

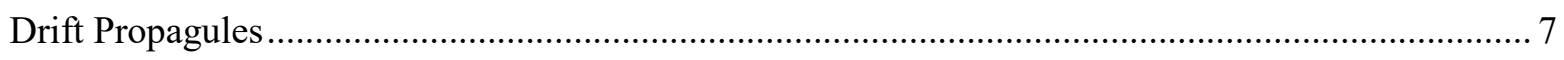

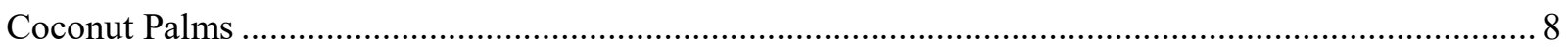

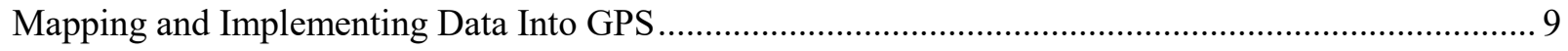

Description of the Vegetation in the Different Areas ................................................................... 9

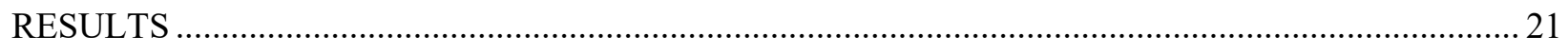

A Very Depauperate Flora and Important Species Turn Over ...................................................... 21

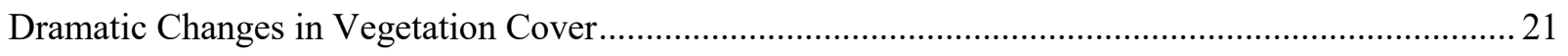

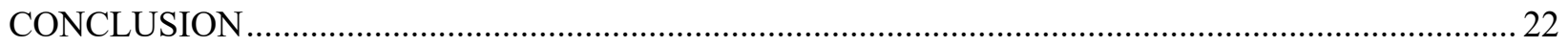

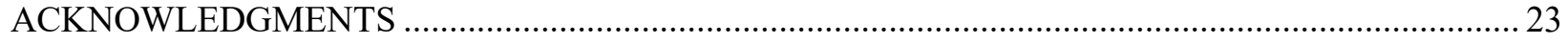

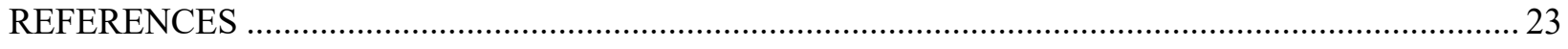

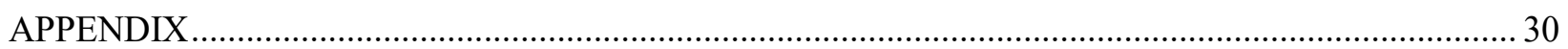




\title{
FLORA AND VEGETATION OF CLIPPERTON (LA PASSION) ATOLL, NORTH-EASTERN PACIFIC OCEAN: THREE CENTURIES OF CHANGES AND RECENT PLANT DYNAMICS
}

\author{
XENIA JOST ${ }^{1}$, CHRISTIAN H. JOST ${ }^{2,3}$ and JEAN-YVES MEYER ${ }^{4}$
}

\begin{abstract}
The terrestrial flora and vegetation of Clipperton (La Passion) atoll, a very remote and small (170 ha of land) French island located in the North-Eastern Pacific Ocean, at ca. 1,000 km west of the Mexican coast, have dramatically changed during the past three centuries. This paper, based on historical testimonies, previously published floristic studies, and an extensive plant inventory conducted during the "International Scientific Expedition PASSION 2015", show that the atoll has experienced particularly active and rapid vegetation dynamics with alternating plant cover expansion and regression phases. Our results provide the first comprehensive assessment of vegetation cover and vascular plant species distribution based on georeferenced data and mapped with GIS software, as well as the first record of two newly established non-native weeds. The current composition and abundance of native and alien vascular plant communities ( 15 species including only 4 native taxa) appear to depend not only on abiotic factors (e.g. substrate and climatic events) but also on biotic interactions with animal communities (e.g. native seabirds and crabs). Anthropogenic activities and disturbances (e.g. coconut palm, pig, rat and weed introductions) that have occurred in the past 100 years have also played an important role in explaining the past and current floristic changes.
\end{abstract}

\section{INTRODUCTION}

The atoll of Clipperton, a French territory also called La Passion ${ }^{5}$, is located in the Tropical NorthEastern Pacific Ocean at $109^{\circ} 12^{\prime} \mathrm{W}$ and $10^{\circ} 17^{\prime} \mathrm{N}$ (Figure 1), $1,080 \mathrm{~km}$ West of the nearest continental land (Mexican coast), 3,980 km from the Marquesas Islands (French Polynesia), the nearest land being Soccoro Island in the Revillagigedo Archipelago (Mexico) $945 \mathrm{~km}$ away. The total surface of the atoll with its lagoon is 9 sq. $\mathrm{km}$, with 170 ha of emergent coral ring, including six tiny inner lagoon islets. Clipperton is unique because of the presence of a volcanic rock (called "Le Rocher" or "The Rock") rising at $29 \mathrm{~m}$, and a completely closed lagoon (Figure 2). It is the smallest of the 11 French Overseas tropical island territories (comprising French Polynesia, New Caledonia and Wallis et Futuna in the Pacific Ocean) and is considered one of the most isolated uninhabited islands in the world. Despite its small land area, Clipperton affords France sovereignty over 435600 sq. km of ocean (Economic Exclusive Zone).

${ }^{1}$ ENSAM Montpellier SupAgro, 2 place Pierre Viala, 34060 Montpellier, France

${ }^{2}$ Université de la Polynésie française, B.P. 6570, 98702 Faaa, Tahiti, French Polynesia

${ }^{3}$ PSL Université Paris, EPHE-UPVD-CNRS, USR 3278 CRIOBE, B.P. 1013, 98729 Papetoai, Moorea, French Polynesia

${ }^{4}$ Délégation à la Recherche, Gouvernement de la Polynésie française, B.P. 20981, 98713 Papeete, Tahiti, French Polynesia

${ }^{5}$ A text adopted by the French Assembly in November $24^{\text {th }}, 2016$ indicates that the names of La Passion or La Passion-Clipperton can also be used. 


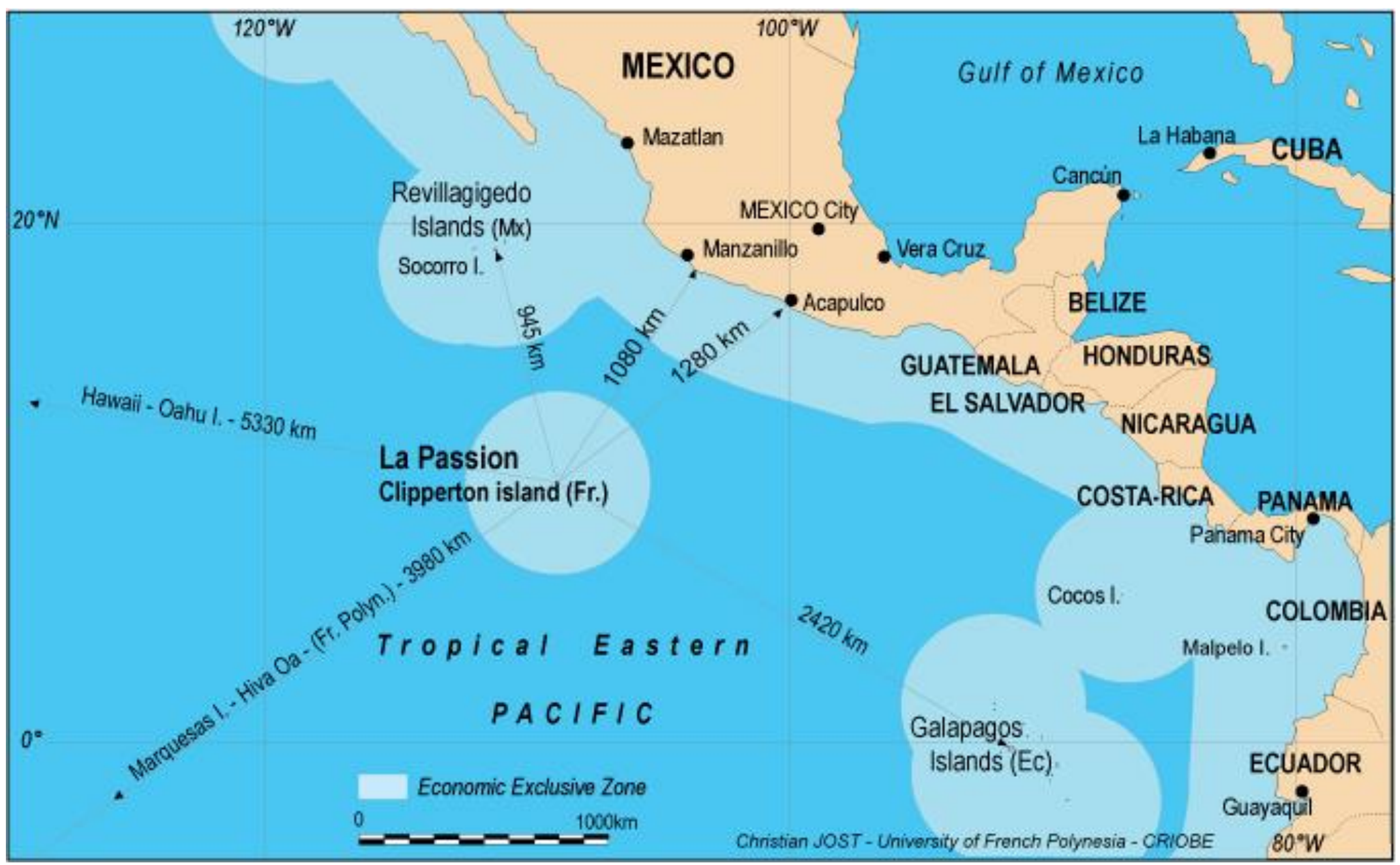

Figure 1. Location of Clipperton (La Passion) atoll in the Tropical North-Eastern Pacific Ocean 


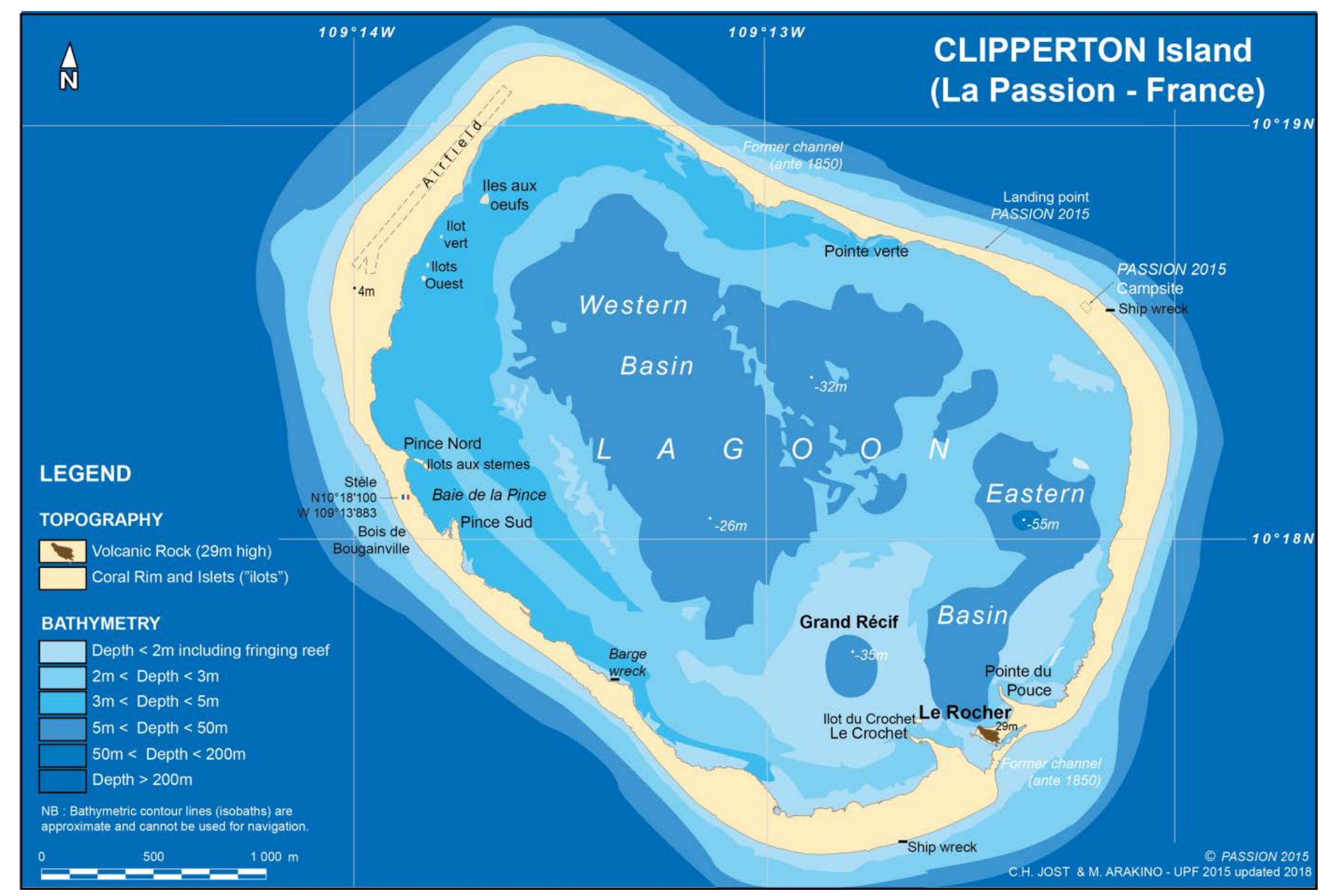

Figure 2. Description of the atoll with the main area toponyms including the location of "Le Rocher" and the six inner lagoon islets 


\section{A Brief History of Past Visits and Scientific Surveys}

Clipperton was first discovered and named "La Passion" in 1711 by the French Captain Michel Dubocage en route to China on his vessel "La Découverte" (Briot and Briot, 2010). During the past three centuries, the island went through periods of strong interest, alternating with long periods of forgetfulness. In 1858, Lieutenant Le Coat de Kerveguen took official possession of Clipperton for France, but in 1892, a US citizen, Frédéric Permien, reclaim the island on behalf of the USA, relying on the "Guano Islands Act". He created the Oceanic Phosphate Company to exploit the guano. In 1897 the Mexicans landed a military garrison and guano workers stayed on the island until 1917.

Although the next visits on this very remote island were sparse, the number of scientific and report papers are numerous, exceeding 500 (Jost, 2005a), allowing comparative studies of the natural environmental of the atoll, both in the lagoon and on land. The French Army and the Oceanographic and Hydrographic Service (SHOM) established the first map of reference in 1935. One of the first and most important scientific surveys was conducted in 1958 by the Scripps Institution of Oceanography based in California, with 13 scientists including the French botanist Marie-Hélène Sachet. The French Army occupied the island through continuous trips called "Missions Bougainville" from 1966 to 1969 (Ehrhardt and Niaussat, 1970). The famous French oceanographer, researcher, filmmaker, and undersea explorer, Jacques-Yves Cousteau visited the atoll in 1980 with a small French-Canadian-American scientific team. A Mexican-French scientific expedition "SURPACLIP" was organized in November 1997 directed by Dra Solis-Weiss (Universidad Nacional Autónoma de México) with the participation of the second author (then based at the University of New Caledonia) who later organized the "PASSION 2001" expedition with scientists from IRD (Institut de Recherche pour le Développement) and the help of the French Navy. A large scientific expedition was organized by the French explorer Jean-Louis Etienne between December 2004 and April 2005 with 30 French scientists rotating every two weeks (Charpy, 2009). The "PASSION 2013" expedition was again organized by the second author (then based at the University of French Polynesia). Throughout these expeditions, detailed observations and data were gathered on plant and animal communities in the lagoon and on land (Jost and Andréfouët, 2006).

The "International Scientific Expedition PASSION 2015", organized and directed by the second author and involving 14 scientists, took place in April 2015. It was held under the high patronage of M. François Hollande, former president of France, sponsored by several French Ministries and Agencies, and with the logistical assistance of the French Navy and Army. Its main goals were to continue the inventories of coral reef biota and land fauna and flora, as well as an assessment of coastal dynamics and erosion.

\section{Historical Documentation of The Vegetation}

The description of the natural environment of Clipperton (La Passion) and more specifically of its vegetation and flora, come from episodic short-term visits and stays since the $18^{\text {th }}$ century (Table 1). Visitors (sailors then scientists) described drastic changes in the vegetation from almost no plant cover (in 1871 and 1897) to dense vegetation cover (in 1934 and 1958), followed by a decline in the 1980-1990s, then a new increase of plant cover starting in 2005.

The most detailed description of the vegetation and flora was provided by French botanist M.-H. Sachet during her two and a half weeks spent on the island in 1958 (Sachet, 1959). The low vegetation was then covering almost $80 \%$ of the land (Sachet, 1962). Noticing the presence of 58 feral pigs with dramatic impacts on seabirds and their eggs, decision was taken to eradicate them by shooting. The number of land crabs Johngarthia planata Stimpson 1860 (syn. Gecarcinus planata, Gecarcinidae) then increased up to 11 million in 1968 (Ehrhardt and Niaussat, 1970), suggesting that pigs were regulating the crab population. As a result, the vegetation cover declined to become totally absent on the coral rim as 
described by Jost in 1997 and 2001, except for coconut trees, and six plant species found on five inner lagoon islets not reachable by crabs (Jost, 2003).

The black rat Rattus rattus was accidentally introduced between 1997 and 2001, probably by a ship stranding (Lorvelec and Pascal, 2009). In 2005 a new census of the crab population showed that they decreased significantly to 1.25 million, suggesting high predation by rats (Bouchard and Poupin, 2009). C.H. Jost suggested that, despite the observation of remains of up to 20 crabs in each rat's nest, the rodent population, estimated at less than a 1000 in 2013, appeared insufficient to explain the strong decline of crabs (Jost, 2013). The crab population might have reached its demographic optimum, and possibly the island's carrying capacity, then declined because of the scarcity of food resources. During the 2005 expedition, only a few patches of vegetation, mainly composed of the vine Ipomoea pes-caprae (Convolvulaceae), were observed (Couté and Garrouste, 2009), while in 2013, vegetation was covering one third of the atoll land surface (Jost, 2013).

The main purpose of this paper is to give a precise assessment of the current terrestrial vascular flora and vegetation of the atoll. It updates the last plant inventory conducted 10 years earlier, and provides the first georeferenced inventory of the vegetation cover, using the Quantum GIS software.

\section{METHOD}

\section{Field-Work Constraints}

Scientific surveys and field work on Clipperton (La Passion) are constrained by the strong geographic isolation and remoteness of the island, the difficulty in accessing the closed atoll by boat, and by the lack of housing infrastructure. Indeed, three to four days navigation are necessary to reach the island from the closest land, i.e., the east coast of Mexico, and seven to eight days from the Marquesas islands (French Polynesia) to the Southwest. The landing, and above all the re-boarding are always dangerous due to the lack of channel to reach the lagoon. Moreover, the atoll is located in the tropical Northeastern Pacific zone of cyclone formation which lasts from mid-May till the end of November.

During the "PASSION 2015" expedition conducted around and on the atoll, weather conditions were fairly good during most of the 16 days spent on land except for two severely stormy days with heavy rains.

\section{Plant Collection and Identification}

Two fertile (i.e., with fruits and/or flowers) samples of each plant species observed during the 16 days of field-survey were collected by the first author. Plant specimens were labelled (with the date of collection, the location, and a collection number), pressed in newspapers, and dried in full sun. The plant collection was preserved in plastic bags with a small amount of $90 \%$ alcohol during the boat trip back to Tahiti, and species identification was confirmed or completed by the third author.

This plant collection is temporarily stored at the "Délégation à la Recherche" in Tahiti (French Polynesia) and will be permanently deposited in the main herbaria of Paris ([P]) and the Musée de Tahiti et des Îles in Tahiti [PAP]).

A few samples of plant material were also dried in silica gel for further genetic analysis and phylogeographic studies. Some seeds and fruits found on the ground in the intertidal zone ("drift propagules") were also collected.

\section{Coconut Counting}

Coconut palms (Cocos nucifera, Arecaceae) were counted, following a method used during past surveys (2001 and 2013) on $10 \mathrm{~m} \times 10 \mathrm{~m}$ squared plots in all coconut groves found on the atoll, with the 
assistance of the French Navy and Army. Their height was visually assessed from the ground to the top of the stipe (or trunk). Dead coconut trees (i.e., without leaves) were counted in 2001 and 2013, and distinguished from those cut by people, often at a man's height.

\section{Vegetation Mapping}

The different vegetation zones were identified, characterized and located by repeated and crossobservations made by two observers and using two indexes: the relative plant cover rate of each species in a specific area and the level of aggregation of each species (aggregated or scattered).

Areas which appeared to be homogeneous (either mono-specific, i.e., dominated by one species, or by an association of two species and up to six) were delimited and called hereafter "vegetation zones."

In order to survey the whole land area of the atoll in a relative short period of time, quadrats and transects were not set up. The cover rate of each species and of the bare soil (uncovered land) of the different vegetation zones were evaluated in relation to the surface of the study area, using the BraunBlanquet method (Braun-Blanquet, 1928). This approach consists of using a constancy class that is the percentage of occurrences within the sampled zone: 0-5\% (rare constancy), 5.1-25\% (low constancy), $25.1 \%-50 \%$ (intermediate constancy), 50.1-75\% (moderately high constancy), and $75.1-100 \%$ (high constancy).

The delimitation of these zones was realised with a GPS (Garmin Etrex 10 GPS) in the WGS84coordinate system. These data collected in the field were imported into the Geographic Information System (GIS) software Quantum (2.2.0 version Valmiera). The base map used was from a Worldview geo-referenced satellite image dated 18 Sept. 2014.

In addition to the plant cover index, we used the specific richness, which is the number of species occurring in a vegetation zone. For each zone, each species has been identified, and a map of the species density was realised. When only one species was present, vegetation zone is considered as mono-specific.

Maps of the different vegetation zones, including plant cover rates, species number, vegetation types (according to species life forms), dominant species in each zone, were produced. These geo-referenced maps represent also a zero-reference state that will ensure a temporal and spatial comparability between the different indicators (plant cover percentage, abundance/dominance, and expansion/recession dynamics).

\section{RESULTS}

\section{Plant Diversity}

\section{List of Species}

Fifteen species of terrestrial vascular plants, all phanerogams and angiosperms (no pteridophyte nor gymnosperm was observed), belonging to 11 different families were recorded in April 2015 (Table 2), as well as three aquatic plant species.

By comparison, a total of 27 terrestrial plant species were reported in 1958 (Sachet, 1962), 11 species in 2005 (Couté and Garrouste, 2009) and only nine in 2013 (Jost, 2013). Four aquatic plant species were recorded in 1958 (Sachet, 1962) but only two in 2005 (Couté and Garrouste, 2009) (Table 3).

\section{Biogeographic Status}

The geographic origin of some of the species is sometimes difficult to assess, especially for plants with a current pantropical distribution. Species of uncertain status (sometimes classified as "cryptogenic", Carlton, 1996) on Clipperton, known as "weeds" in the Pacific Ocean but considered native in the Caribbean islands and tropical America, were considered as accidental or intentional introductions. They include for instance Cenchrus echinatus (Asteraceae), Corchorus aestuans (Malvaceae), Ipomoea triloba (Convolvulaceae), Phyllanthus amarus (Phyllanthaceae), Portulaca oleracea (Portulacaceae) and Sida 
rhombifolia (Malvaceae), all recorded since 1958 (Sachet, 1962). The tree tobacco Nicotiana glauca was also probably intentionally introduced as a useful plant (Sachet, op. cit.).

We considered four species as native or indigenous: two of American/Caribbean origin (Heliotropium curassavicum and Eleocharis mutata), and two from an American or Asian origin (Ipomoea pes-caprae subsp. brasiliensis and Eleocharis geniculata). It is noteworthy that Eleocharis geniculata, E. mutata, and Ipomoea pes-caprae subsp. brasiliensis are considered as introduced taxa on Clipperton by the "Inventaire National du Patrimoine Naturel" (INPN) taxonomic database ${ }^{6}$. We have considered Achyranthes aspera var. aspera (Amaranthaceae) and Salvia occidentalis (Lamiaceae) as human introductions as they were noted only recently.

Among the 15 recorded species, 11 are considered as "introduced" species, i.e., $74 \%$ of the total, and four are considered "native", i.e., 26\% (Table 4). No endemic species are recorded on the atoll.

\section{Newly recorded Plant Species}

Two introduced and naturalized species were newly discovered: Achyranthes aspera var. aspera (Amaranthaceae), an erect or shrubby herb with a pantropical distribution, and Salvia occidentalis (Lamiaceae), an annual herb or sub-shrub native to Mexico, South America and the Caribbean islands.

Achyranthes aspera var. aspera, is considered as a "weed" in the Pacific islands and was probably introduced to Clipperton by visitors because of its seeds with spiny bracts that adhere to animals and clothing. In 2015, this species was seen in almost all vegetated areas, demonstrating a relatively high rate of dispersal (probably by seabirds) and high colonizing capacities. Salvia occidentalis was only found at one location, southwest of the airstrip forming a relatively dense mat (Photo A, $\boldsymbol{c f}$. Appendix).

\section{Species Not Found}

Between 1958 and 2005, 17 species of terrestrial phanerogams have disappeared from the atoll (Table 3). Most of the missing species appear to be introduced weedy plants, and more than $70 \%$ of them are herbaceous. Between 2005 and 2013 two additional species were missing, including the small tree Hibiscus tiliaceus (Malvaceae) only recorded in 2005 as a single individual (Couté and Garrouste, 2009), and the creeping vine Canavalia rosea (Fabaceae).

Four species observed in 1958, and not mentioned in 2005 and 2013, were observed again in 2015: Phyllanthus amarus, Eragrostis ciliaris (Poaceae), Cenchrus echinatus and Nicotiana glauca. They were either dormant (as seeds in the soil seed bank), or too rare to be noticed, or accidentally reintroduced between 2013 and 2015. We also found drift seeds of the vine Mucuna sp. (Fabaceae) which was only recorded in 1958 as living plants.

It is interesting to note that the number of introduced "weedy" species is higher during the periods of relatively important plant cover (in 1958 and 2015), compared to the periods of sparse plant cover (in 1997, 2001 and 2005), suggesting that native species appear to be better adapted or more resilient to harsher ecological conditions.

\section{Drift Propagules}

Seeds and fruits were searched and collected on the entire shoreline in the intertidal zone. They belong to several different taxa, but only four could be identified: Mucuna sp. (Fabaceae), Entada gigas (Fabaceae) and Dioclea sp. (Fabaceae) which were already reported in previous studies (Sachet, 1962), and a newly recorded species, Lagenaria sp. (Cucurbitaceae), with several large fruits, some of them containing seeds.

\footnotetext{
${ }^{6}$ https://inpn.mnhn.fr/accueil/index
} 


\section{Coconut Palms}

Coconut palms expansion started in 1897 with the introduction of the two first individuals by the guano workers. In 1958, M.-H. Sachet noticed that "there appear to be two main varieties of coconut palms on the island: some have more oval, green nuts, and the rachis of the young frond leaf is also green; others have a bright orange young rachis, and rounder large orange nuts" (Sachet, 1962). These two varieties were observed in 2015 , but their distribution could not be precisely mapped due to lack of time. However, 847 coconut trees over $1 \mathrm{~m}$ were counted in 2015 (Table 5). The orange nut variety is much less common than the green one, and more abundant on the Eastern coast. There is a regular increase $\left(r^{2}=0.9259\right)$ of the number of coconut palms during the past 120 years (Figure 3 ) which does not distinguish the two varieties.

We noticed that the number of dead, headed and cut coconut trees was less than during previous visits. The combined total was 85 in 2015 (of which 62 were topped and 23 cut), compared with 91 topped or cut in 2013 and 168 in 2001 ( no distinction between topped and cut palms). In 2015, the trunks without leaves were numerous (53) on the South coast in the old palm grove of Bougainville which seems to be reaching the end of its life. The topping seems to be related to age and weather events. Cut stems, obviously with a machete or an axe (presence of cutting lines at human height), are, on the other hand, a large majority on the North-East coast (21 out of 23), which is more frequented by humans, where landings are reported more numerous, but also where helicopter drops (purse seiners in operation) have been recorded.

Despite an increase in the total population of palms, living trunks (above $1 \mathrm{~m}$ in height) have diminished in the "Bois de Bougainville" from 479 in 2001, to only 305 in 2013. We also noticed in 2013 and in 2015 a total lack of undergrowth in this dense coconut grove (Photo B, $\boldsymbol{c f}$. Appendix). This could be explained by the age of the grove, which corresponds to the first two specimens planted in 1897 (a coconut tree gives fruits for ca. 70 years and can live around 100 years) but also partly by the cleaning of the undergrowth for the installation of the camp of the "Jean-Louis Etienne expedition" in 2005. The other (younger) groves, located mainly on East and North coast, are rapidly expanding and have dense undergrowths of young palms.

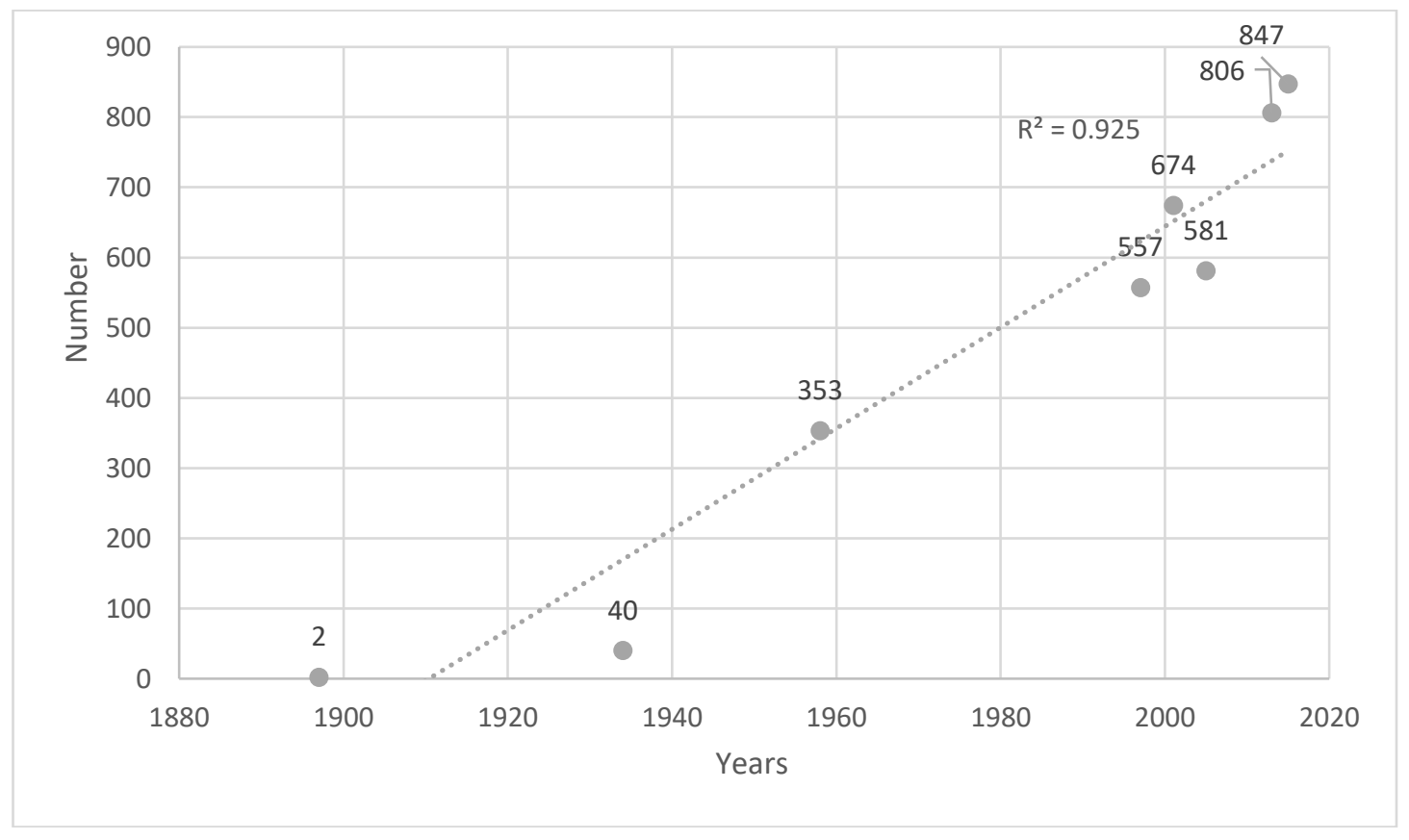

Figure 3. Increase of coconut trees between 1897 and 2015 


\section{Mapping and Implementing Data Into GPS}

After processing the GPS data, various maps were developed using Quantum GIS. Figure 4 provides information on the percentage of plant cover over the entire atoll ring, that is, the cover of all plant species by vegetation zone. A total of 68 vegetation zones were identified. As described in the methodology, the percentage of cover of each species is given as well as the percentage of bare soil. As an example, the vegetation zone named " $3 \mathrm{C}$ " located near the "Bois de Bougainville" is composed of Heliotropium curassavicum (30\%), Achyranthes aspera (5\%), Portulaca oleracea (15\%), and the bare soil represents $50 \%$ of the surface of the zone.

The entire cover extension of vegetation delimitated represents a total of 79 ha (46.5\%). Most of the vegetation zones (68 in total) are dense, comprising between 50 and $100 \%$ of plant cover. Zones with a cover above $75.1 \%$ and up to $100 \%$ represent 46.7 ha, those with a cover between $50.1-75 \%$ represent 27.3 ha, and only one zone has a plant cover between 5.1-25\%, representing 0.11 ha. Figure 5 illustrates the different vegetation zones (in hectares) related to the percentage of bare soil within a zone.

The zones whose coverage is $75.1 \%$ to $100 \%$ are located along the West and East parts of the atoll. Those with a 100\% cover are mainly composed of Ipomoea spp. native and introduced vines and the native tufted sedge Eleocharis geniculata located near the lagoon, on the East coast and on the West coast beside the airfield, and at the Southern side of the "Bois de Bougainville".

Figure 6 presents the specific richness for each zone. An average of three to four species are found in closed association. Several zones have six associated plant species, two of which are very extensive: one located in the North-West and the second in the South, both with a vegetation zone of more than 11 hectares. Monospecific zones are mainly represented by Ipomoea spp. vines, but also by species such as Heliotropium curassavicum and E. geniculata mainly at the edge of the lagoon.

The three species are present in the largest number of zones: the native erect herb Heliotropium curassavicum with 29 out of 68 zones (43\%), the introduced erect herb Corchorus aestuans (22 zones or $32 \%$ ) and the native sedge Eleocharis geniculata (22 zones, 32\%). These three species are present on almost the entire ring. In contrast, species such as Nicotiana glauca and Salvia occidentalis are only found at one location, e.g., on the ring at the Southern tip of the island for the tree tobacco with 16 stems of more than a meter high (Photo $\mathbf{C}, \boldsymbol{c} f$. Appendix).

Four main vegetation types can be distinguished on the atoll, namely sub-shrub stands, herbaceous stands (erect or prostate herbs), creeping vines stands, and coconut groves, but with different plant composition and abundance according to geographic areas (Figure 7).

\section{Description of the Vegetation in the Different Areas}

"Le Rocher" Area - Heliotropium curassavicum is particularly abundant, associated with small areas of Corchorus, Portulaca oleracea and Sida rhombifolia. On the East side of "Le Rocher" two groups of Ipomoea spp. vines are competing with each other (Photo D, cf. Appendix), I. pes-caprae in the South and I. triloba in the North (Photo E, $\boldsymbol{c f}$. Appendix). Some patches of both species of Eleocharis (E. geniculata and E. mutata) are also found in contact with the lagoon at the base of "Le Rocher".

Southern End Of The Atoll - A large stand of Eleocharis mutata surrounded by Eleocharis geniculata (Photo F, $\boldsymbol{c f}$. Appendix) is found at the Southern end of the atoll, near "Le Crochet". Going Westward from this tip, vegetation consists mostly of erect and tufted herbaceous plants dominated by Heliotropium curassavicum, Corchorus aestuans, Portulaca oleracea, and Eleocharis geniculata. The latter forms a monospecific stand bordering the shoreline of the lagoon side up to "Le Crochet" peninsula. In the immediate vicinity of Eleocharis another monospecific stand of Ipomoea triloba is found. Shrub stands with Sida rhombifolia and Achyranthes aspera are observed in the Western part of this area, parallel to the shoreline and located in depressions of probably former phosphate mining areas (Figure 8). 


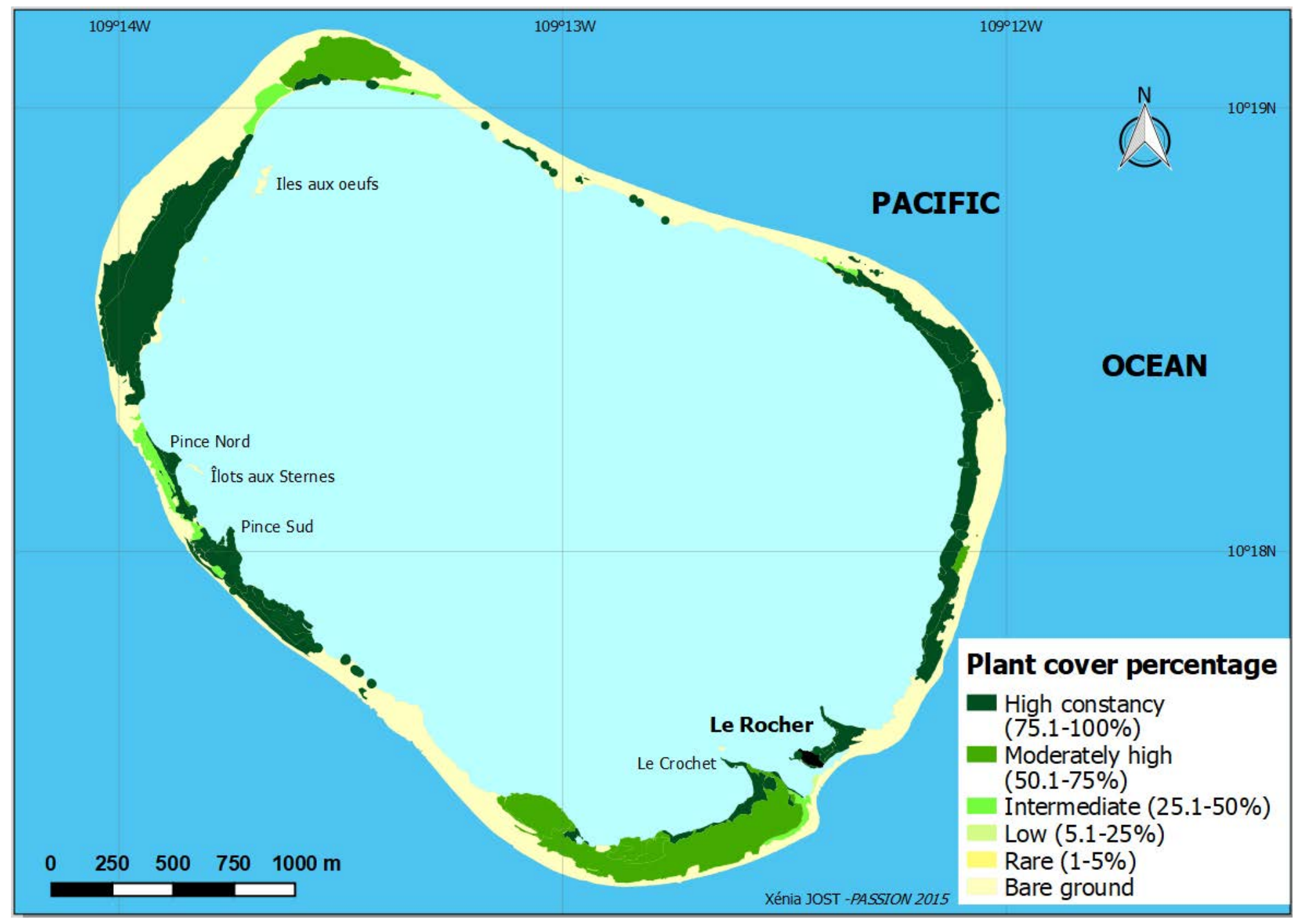

Figure 4. Spatial distribution of vegetation zones according to plant cover 


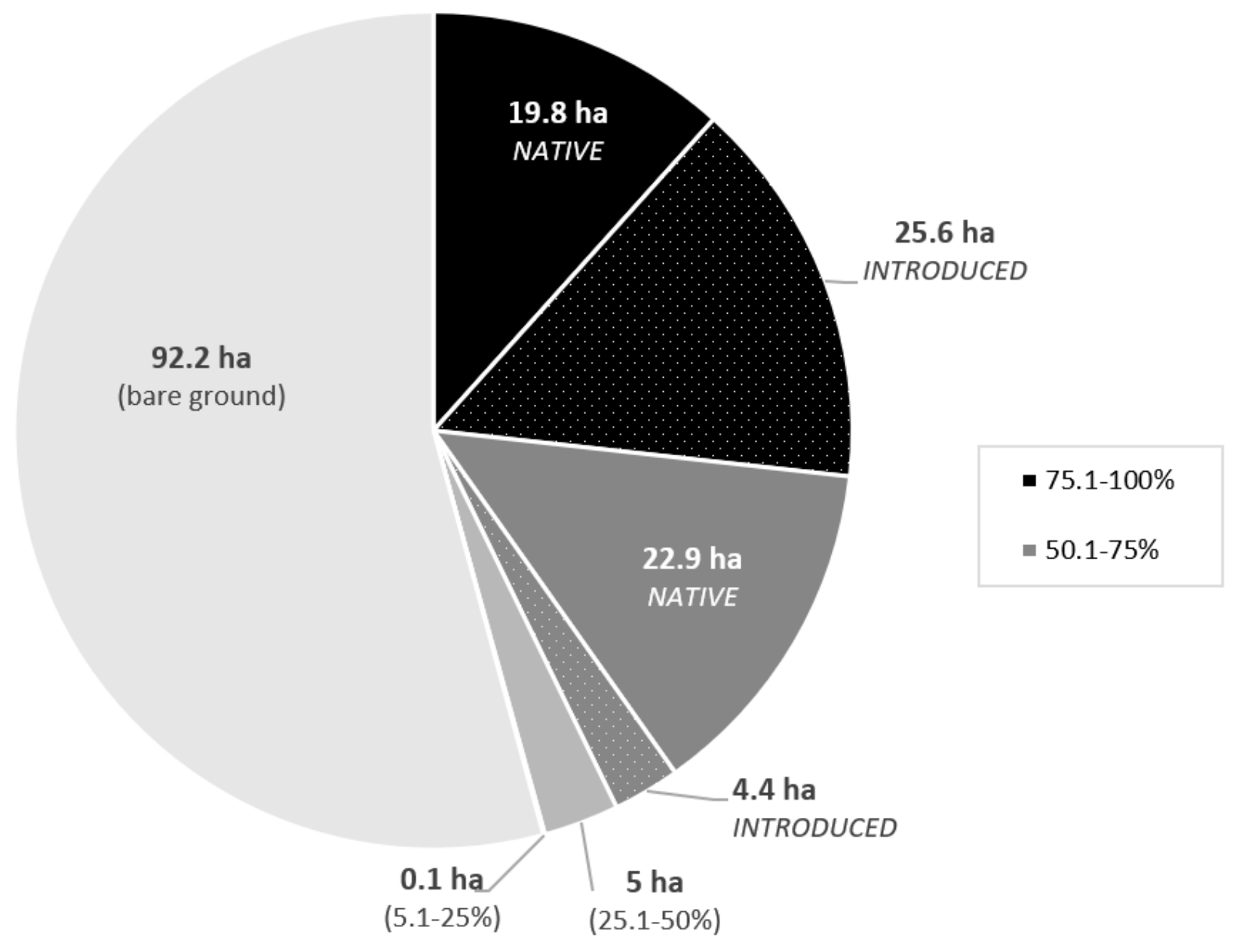

Figure 5. Areas (ha) of all vegetation zones $(\mathrm{N}=68$ ) according to plant cover (in \%) and species status (native or introduced) 


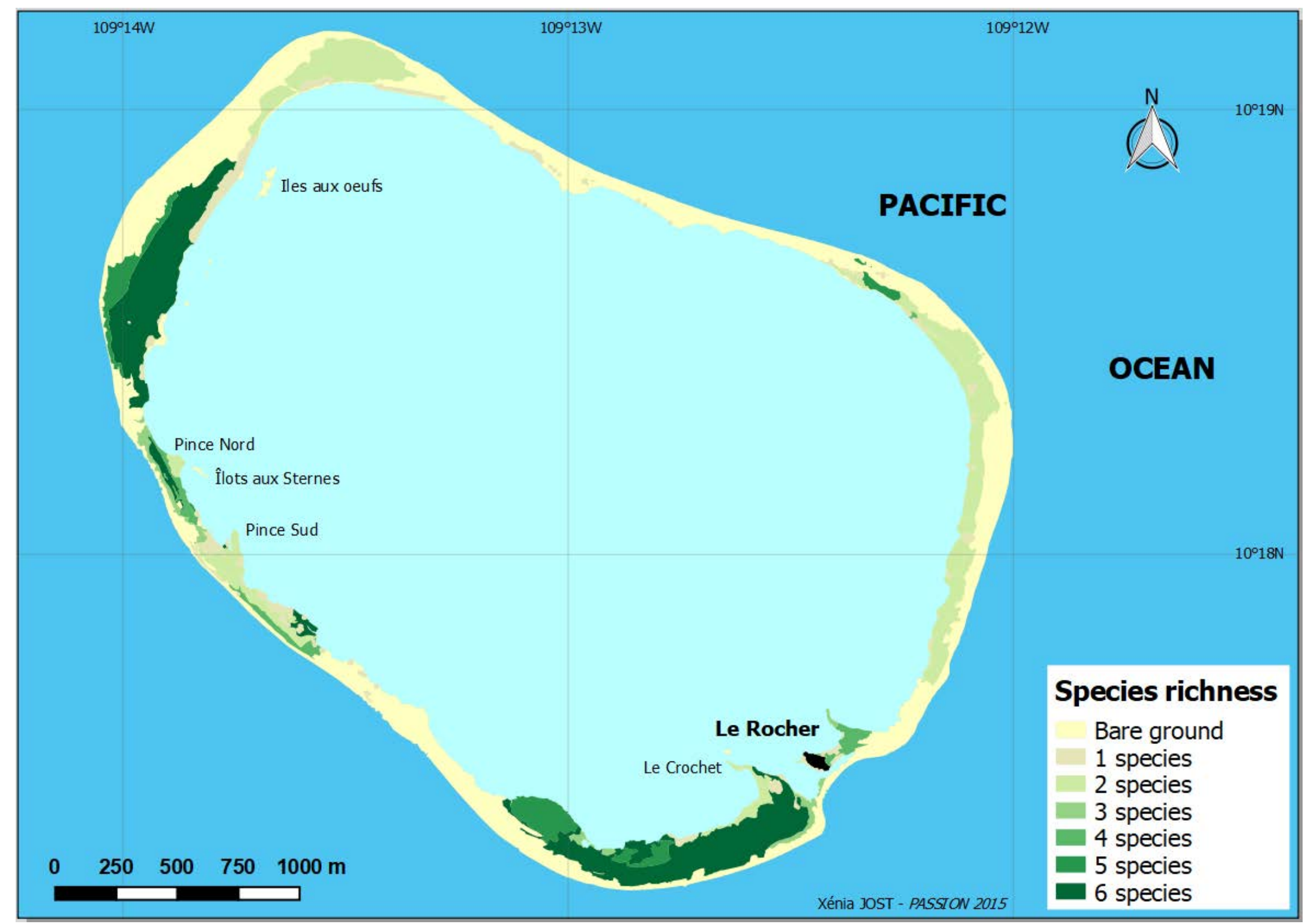

Figure 6. Spatial distribution of plant species richness 


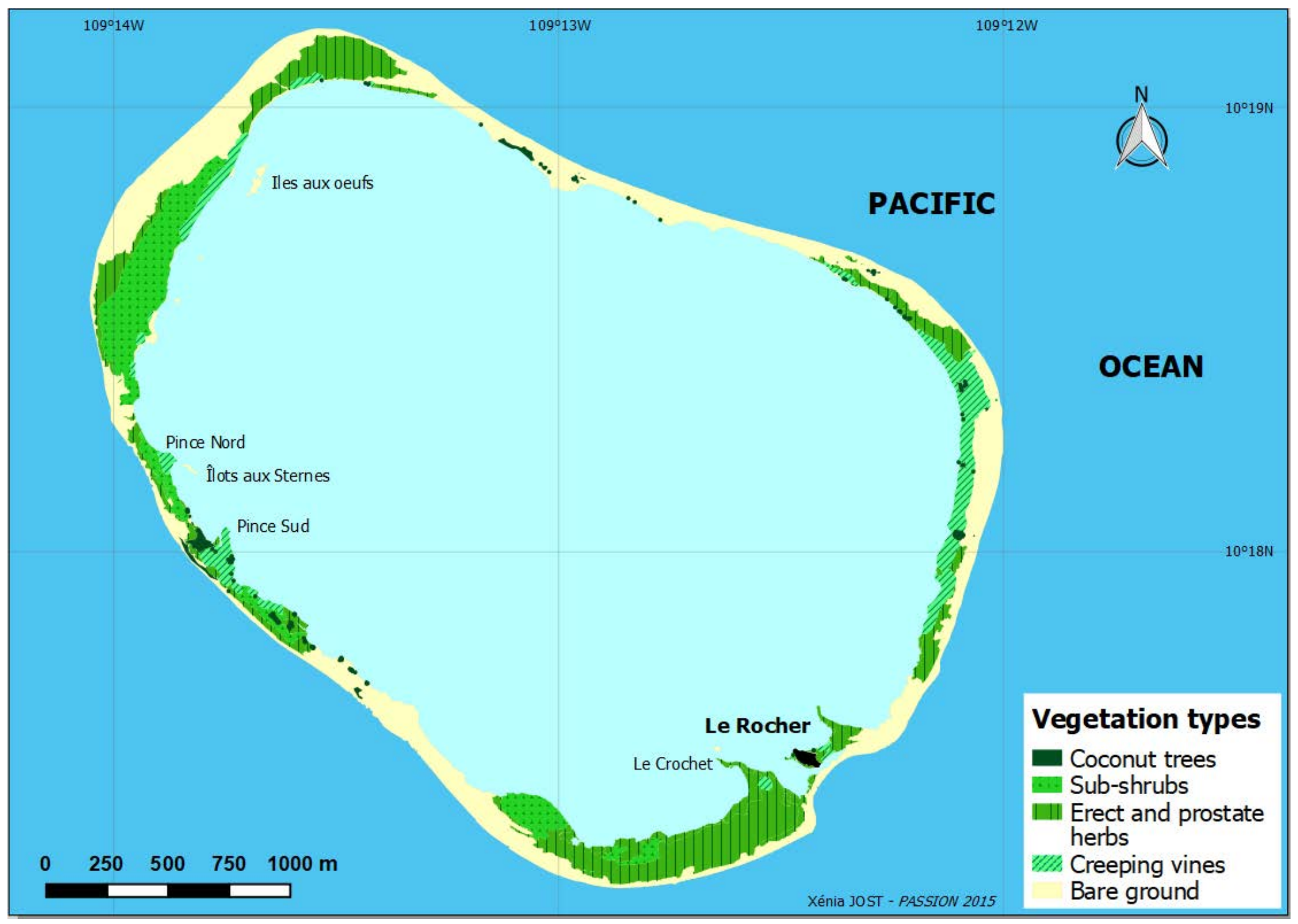

Figure 7. Spatial distribution of the four main vegetation types 


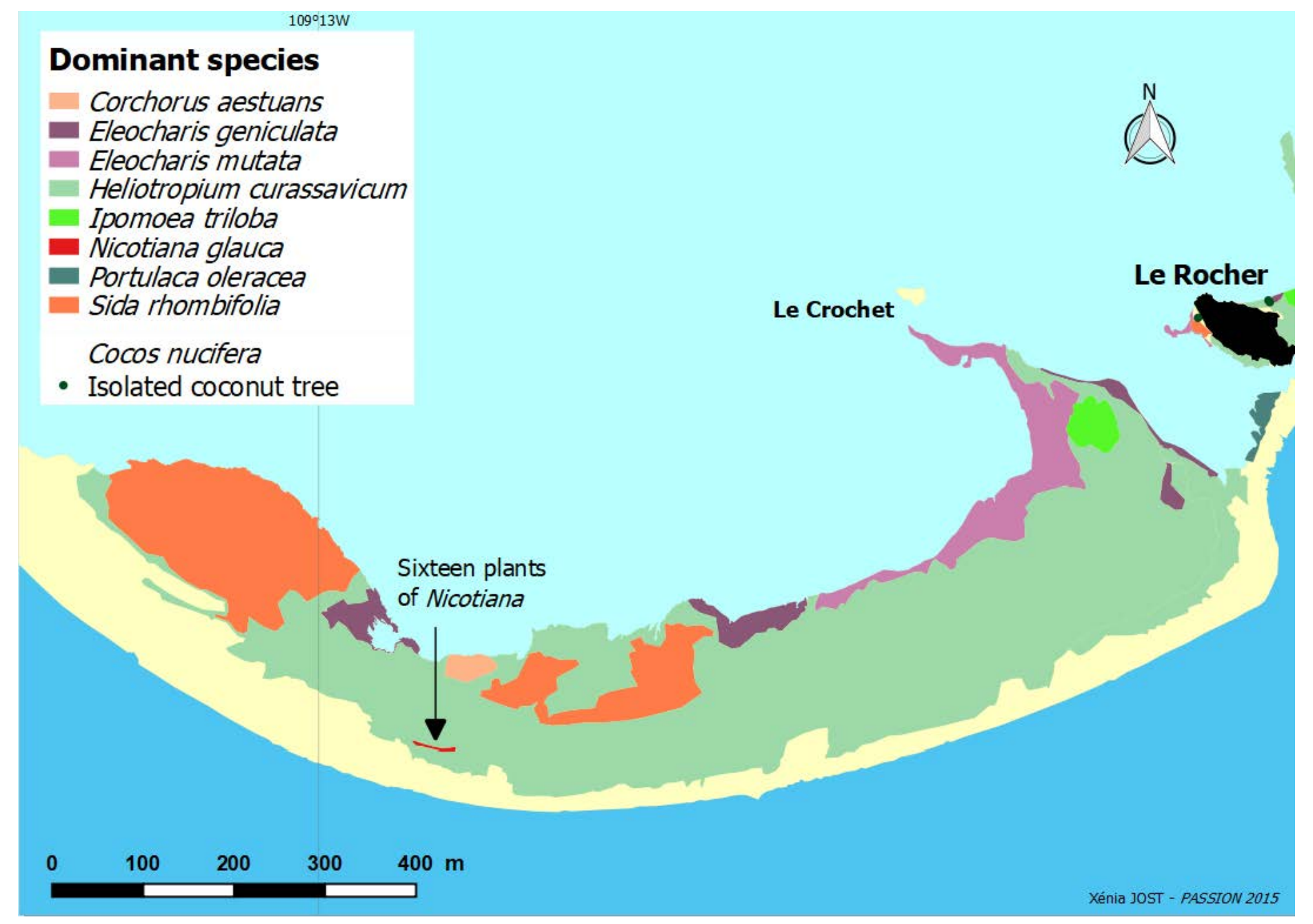

Figure 8. Spatial distribution of the dominant species on the Southern end part of the atoll 
"Bois De Bougainville" Area Including "Pince Sud" And "Pince Nord" - The "Pince Sud" is entirely covered by Ipomoea vines ( $80 \%$ of Ipomoea triloba and $20 \%$ of Ipomoea pes-caprae) (Photo G, $\boldsymbol{c f}$. Appendix). Couté and Garrouste (2009) have noted in 2005 that Ipomoea pes-caprae forms "an almost continuous cover $[\ldots]$ along the Pince Sud [...]". On the small peninsula facing the "Pince Sud" on its West side, a continuous and dense stand of Eleocharis mutata is found growing in the water Southeast of the "Pince Sud", two other patches of Ipomoea triloba are found beside the lagoon while Ipomoea is replaced Southward by a cover of Achyranthes aspera in the middle part of the ring (Figure 9). In 2005 only two patches of Ipomoea were present nearby the lagoon. A strip of Ipomoea is found in association with the shrub Sida rhombifolia. Heliotropium curassavicum is abundant in the vicinity of the lagoon but much more widely spread all along the shore, associated with other plants such as Portulaca oleracea and Corchorus aestuans. In the Northern area of the "Bois de Bougainville" (Figure 10), the "Pince Nord" is covered with Ipomoea pes-caprae vines, largely predominant and covering some Ipomoea triloba (Photo H, $\boldsymbol{c f}$. Appendix). The presence of Ipomoea was not recorded in 2005 but instead "a herbaceous vegetation with Heliotropium and Portulaca, along with some spots of Corchorus aestuans" (Couté and Garrouste, 2009).

On the edge of the "Pince Nord", up to the French monument (called "Stèle" on the map) a shrubby strip of Achyranthes aspera and Sida rhombifolia 50 to $70 \mathrm{~cm}$ in height, associated with other erect herbaceous plants, totally covers the ground.

West And North-Western Area - On the West and largest part of the atoll (300-400 m wide), the most abundant plants are Sida rhombifolia, Cenchrus echinatus and Corchorus aestuans, a plant formation also highlighted in 1958 by M.-H. Sachet. They make up a shrub cover of $30-50 \mathrm{~cm}$ high. Low vegetation formed by Heliotropium curassavicum is found on the edge of this vast and homogenous bushy area on the upper part of the ring and more exposed to salt spray, while patches of Ipomoea triloba are found close to the lagoon (Figure 11). The most extensive Ipomoea triloba stand is mixed with the Ipomoea pescaprae. To the North, at the edge of the lagoon, other small patches of Ipomoea spp. are observed, including a monospecific patch of Ipomoea pes-caprae. The herbaceous Heliotropium associated with Corchorus are forming a low and sparse cover.

North-Eastern Area - On the West side of the base camp of the "PASSION 2015" expedition. The vine stands are mostly composed of Ipomoea triloba, but in association with Ipomoea pes-caprae on the side of the lagoon.

Around the camp, the vegetation is very low and sparse (Figure 12), dominated by Heliotropium curassavicum with Portulaca oleracea and also Corchorus aestuans stretched on a long strip from West to East of the middle low part of the ring. A dense herbaceous cover hardly exceeding $15 \mathrm{~cm}$ high mainly composed of Phyllanthus amarus is found down the camp site towards the lagoon. It is the largest and almost only patch of this species on the island. At the time of Sachet's expedition, this small herb was found at the Northwest of the island and also on the East coast. A monospecific stand of Eleocharis geniculata develops along the shoreline of the lagoon.

From the camp towards "Le Rocher" three groves of coconut trees (C. nucifera) are found, surrounded by large stretches of Ipomoea spp. (Figure 13). The first and second stands of Ipomoea, up to the first grove, are mostly I. triloba, while I. pes-caprae is in the background at the edge of the lagoon (Photo I, cf. Appendix). From the second grove of coconut palms we find again a mixture of the two Ipomoea species but dominated by I. pes-caprae (Photo J, cf. Appendix). The Southernmost Ipomoea stand is the herbaceous tuft Eleocharis geniculata that grows around the lagoon. The Heliotropium curassavicum cover that grows in the center of the ring from North to South is associated with Portulaca oleracea which forms patches within the zone. 


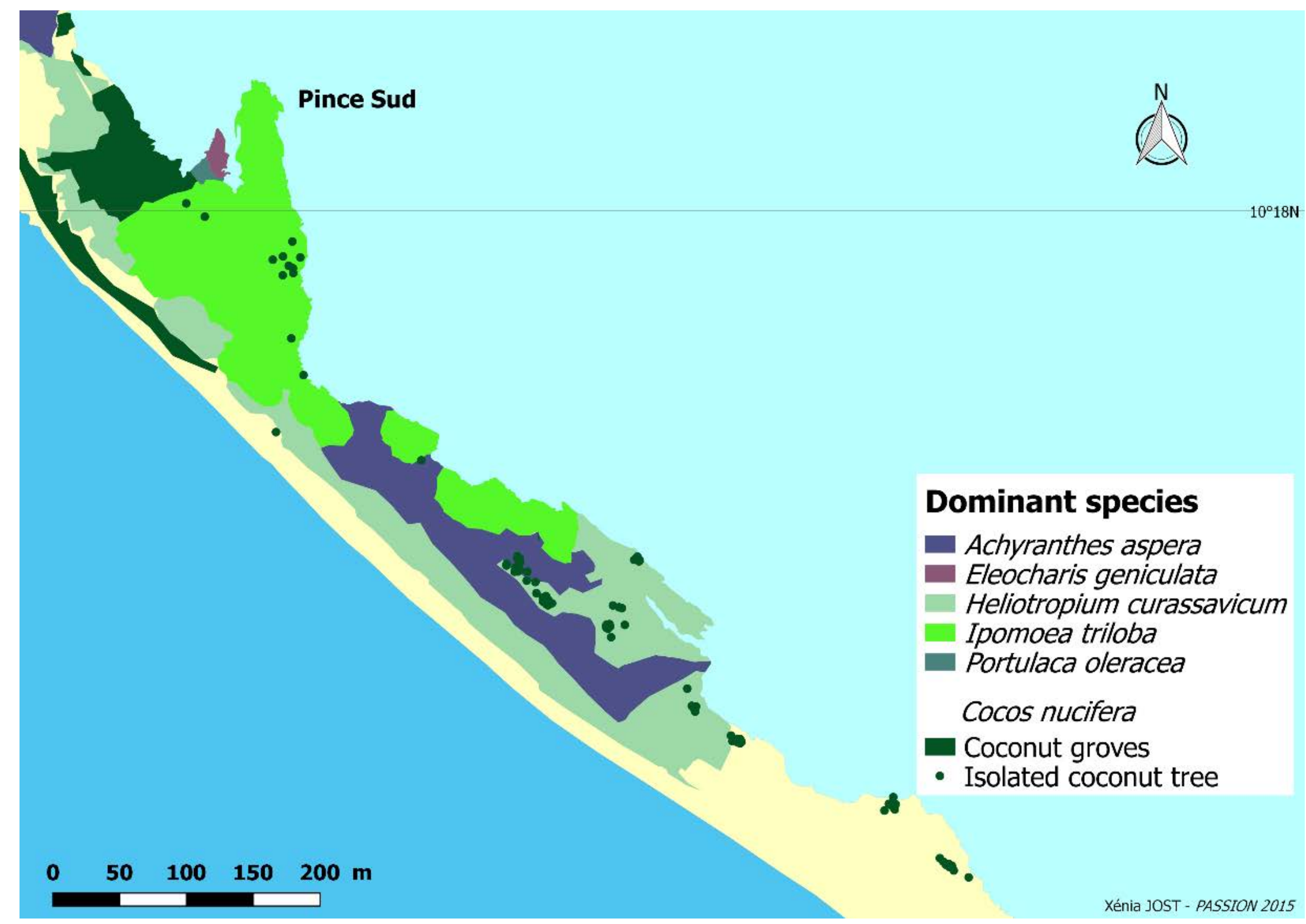

Figure 9. Spatial distribution of the dominant species on the Southern area of «Bois de Bougainville» 


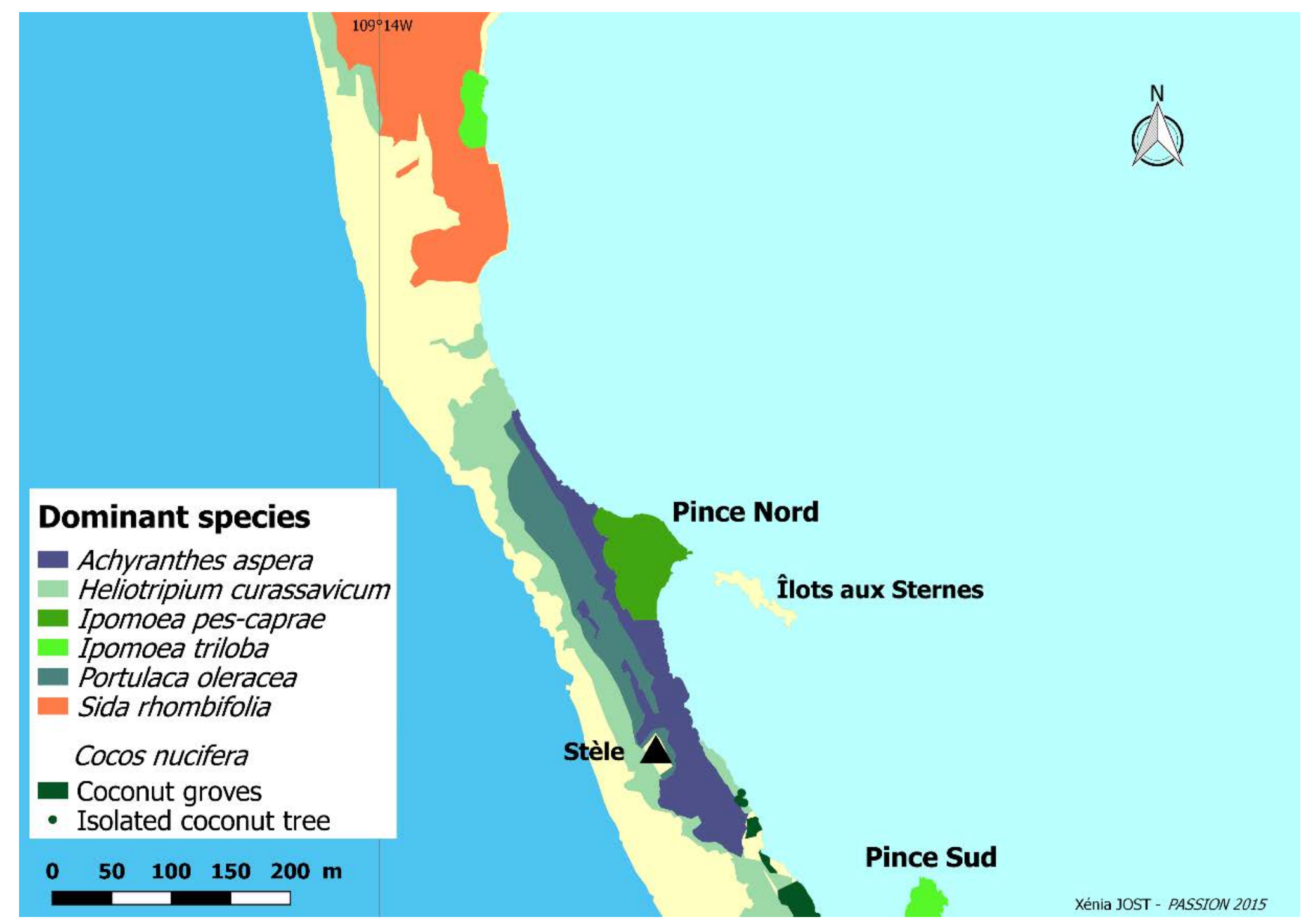

Figure 10. Spatial distribution of the dominant species on the Northern area of « Bois de Bougainville » 


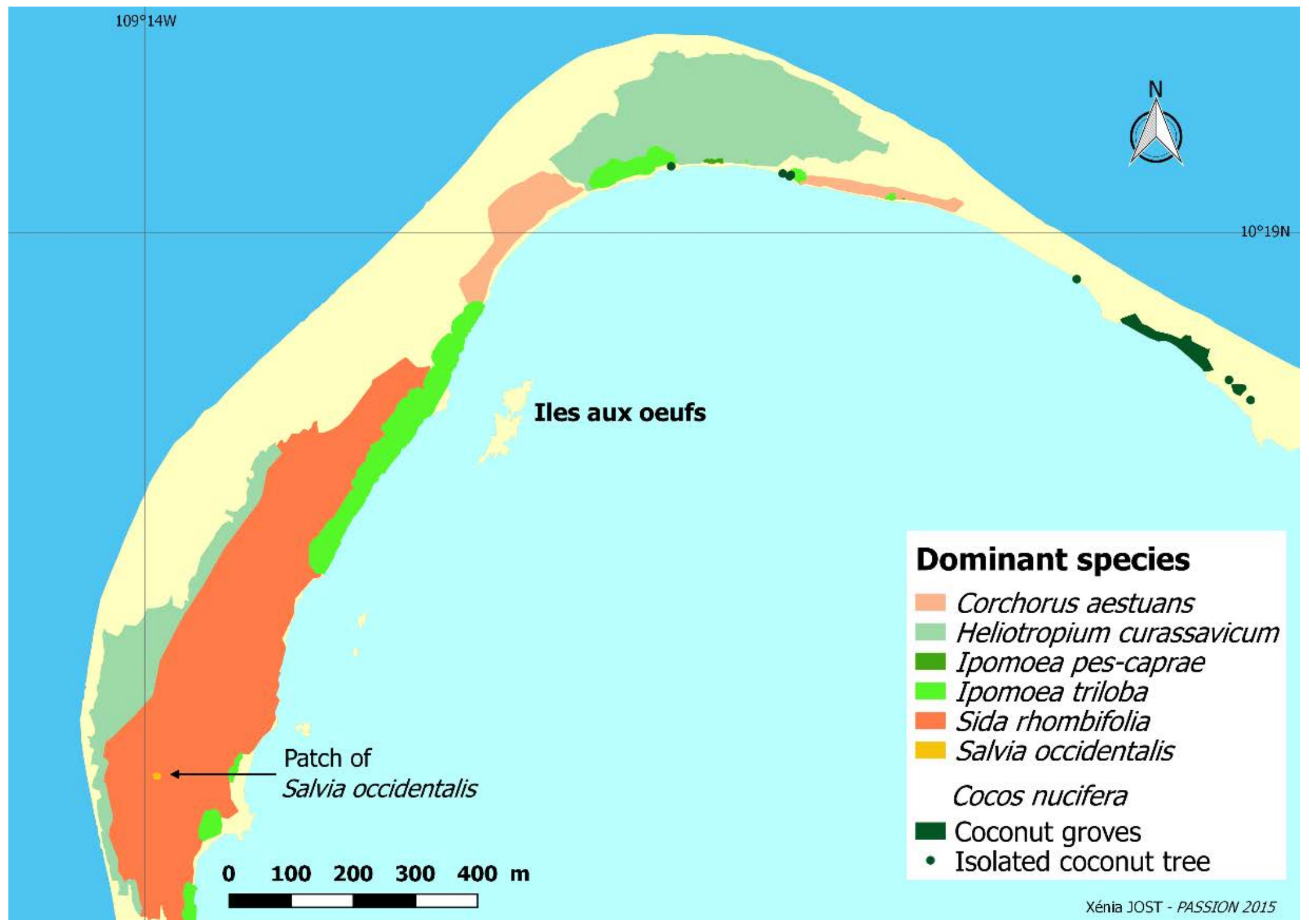

Figure 11. Spatial distribution of the dominant species on the West and Northern area 


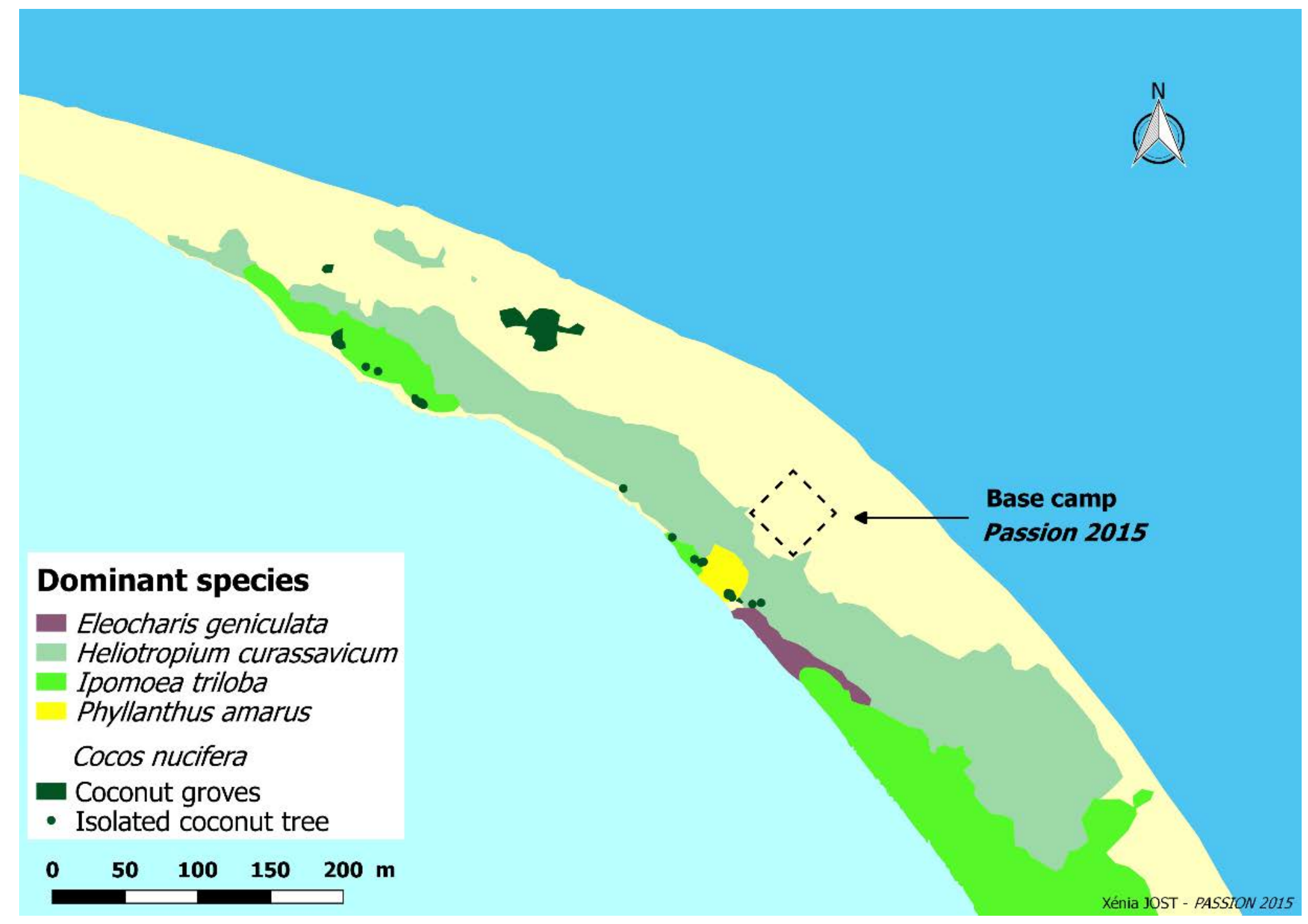

Figure 12. Spatial distribution of the dominant species on the Northeastern area 


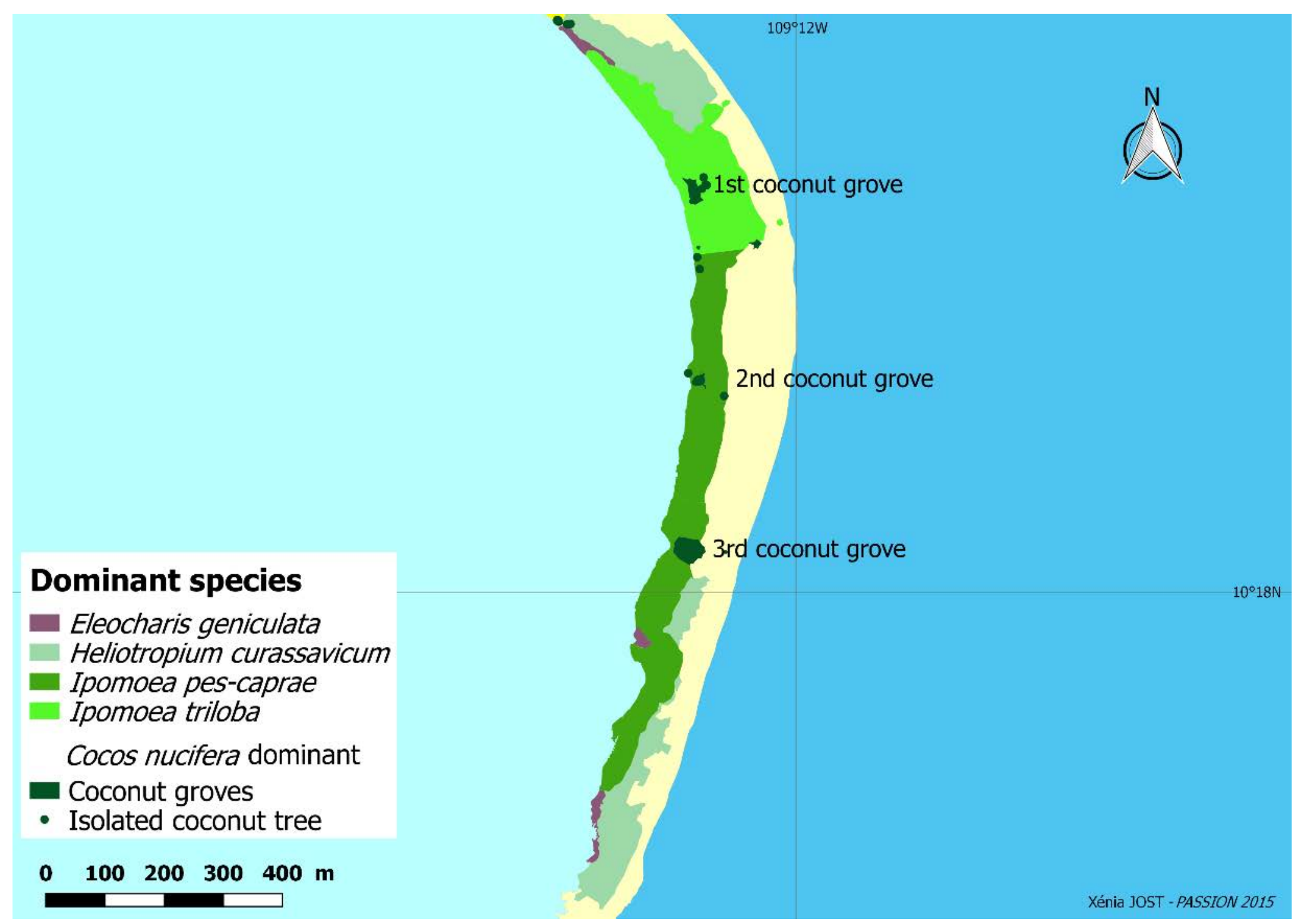

Figure 13. Spatial distribution of the dominant species on the Eastern area with three main coconut groves 


\section{DISCUSSION}

\section{A Very Depauperate Flora and Important Species Turn Over}

Due to its extreme isolation, ca. 1,000 km from the nearest continent (Central America) and $945 \mathrm{~km}$ from the first land, Soccoro island Northward (Mexico), and because of its very small land surface (170 ha) with harsh ecological conditions, Clipperton (La Passion) atoll shows a very low plant diversity. The vascular flora, which comprised 27 species including 9 native taxa in 1958 (Sachet 1962), is currently composed of 15 species including only five native taxa. These last species are particularly well adapted to the dry tropical environments of atolls characterized by nutrient poor calcareous soils with a small amount of organic matter and high salt concentrations, low rainfall, high temperatures, and periodic strong winds and heavy tropical rains during cyclones. Some of them have developed succulent and/or small leaves to reduce respiration and water loss, including the newly recorded alien subshrubs Achyranthes aspera var. aspera and Sida rhombifolia. Some introduced species, on the other hand, are more sensitive to these harsh ecological conditions and do not survive, such as the weed Erigeron bonariensis only recorded in 1958 or Hibiscus tiliaceus present in 2005 but not in 2015.

In 1958, according to M.-H. Sachet, the most common plants found in the atoll were the weeds Cenchrus echinatus, Sida rhombifolia, Corchorus aestuans and Solanum americanum, and "other less abundant plants locally mixed with this vegetation" (Sachet 1962) including Heliotropium curassavicum and the weed Erigeron bonariensis. In 2015, the shrub Sida rhombifolia, was among the most abundant plants, with Heliotropium and Ipomoea triloba, whereas Cochorus aestuans was one of the least common plants. In 60 years, the plant composition has dramatically changed, and some community trends have almost been reversed.

The plant density ranges between 8.8 (15 species) and 15.9 ( 27 species) per sq. km. In comparison, the flora of other atolls in French Polynesia varies between 11.5 for the small $(4 \mathrm{sq} . \mathrm{km})$ uninhabited atoll of Taiaro in the Tuamotu (Niva and Taputuarai, 2013) and 22.7 species per sq. km for the very isolated and uninhabited atoll of Maria (150 ha) in the Austral Islands (Meyer, 2013) but with 25 and 24 native species respectively. The floristic diversity of Clipperton is similar to the small (100 ha) island of Tromelin (Iles Eparses, South-West Indian Ocean), an upraised atoll, with 20 plant species including seven native species (Boullet et al., 2018).

No tree species is found on the atoll, except for the introduced coconut palms (which are not trees botanically speaking). The absence of the small tree Heliotropium foertherianum (syn. Tournefortia argentea, Boraginaceae) and Sophora tomentosa (Fabaceae) or the shrubs Suriana maritima (Surianaceae) and Pemphis acidula (Lythraceae) is noteworthy, as these coastal woody species are commonly found on almost all the atolls and low sandy islands in the Pacific Ocean (Mueller-Dombois and Fosberg 1998). $S$. tomentosa is also known from the Revillagigedo Islands (Johnston, 1931), the nearest land at $945 \mathrm{~km}$ East of Clipperton.

\section{Dramatic Changes in Vegetation Cover}

The vegetation cover of Clipperton (La Passion) atoll has dramatically changed during the past three centuries. The atoll was described as almost a desert between 1858 and 1897, and densely covered by vegetation in the 1960's. A minimum cover was again reached between 1997 and 2001 with not a single species observed on the main land, and only six plant species found in five inner lagoon islets.

It was previously noted that expansion and diversification of the flora were correlative to the demographic growth of pigs from 1897 to 1958 (when pig population was eradicated during the Scripps Institution expedition). However, a few pigs, said to be less than six, escaped the slaughter and were finally killed in 1966 by the French Army during the "Missions Bougainville". Despite the fact that land crabs (Johngarthia planata, syn. Gecarcinus planatus), were already described as an "extremely dense 
population" by Sachet (1962), it seems than their number kept increasing, reaching the spectacular number of more than 11 million in 1967 (Niaussat and Ehrhardt, 1970).

All the studies and observations following the 1958 plant inventory by M.-H. Sachet (Ehrhardt, 1968; Taxit and Ehrhardt, 1981; Jost, 1997, 2001) show a drastic reduction of the plant cover until the disappearance of the grass layer noted for the first time in 1997 (Jost, 1997). Considering this as a process of a rhexistasic period, one can assume that a species introduced by man, the pig, had for once a positive impact at least on the vegetation cover by allowing diversity and extension to develop. Indeed, pigs were observed eating not only bird eggs but also Gecarcinidae crabs whose shells were found in pig feces (Ehrhardt, 1972). The elimination of pigs allowed the multiplication of crabs which consume not only eggs and coconuts, but also the grass cover. The elimination of pigs had a very positive effect on the bird population which exploded between the 1960s and the 2000s from 150 masked boobies (Sula dactylatra) (Sachet 1962) to ca. 100,000 in 2001 and 2005 (Jost, 2003; Jost and Andréfoüët, 2006; Weimerskirch, 2009) becoming the world's most important colony.

However, in 2005 the reappearance and extension of few patches of the herbs, vines and subshrubs was observed (Couté and Garrouste, 2009). This evolution, in correlation with the reduction of the number of crabs, was confirmed in 2013, then in 2015 (Jost, 2013, 2015).

The situations in 2001 and 2005 are difficult to compare since in 1997 and 2001 the only living plants, beside coconut trees, were located in the five inner lagoon islets (Jost 1997, 2005b), unreachable by the land crabs which were confined on main land.

If the factors which can explain these changes were still hypothetical 20 years ago, the recent and more frequent visits and studies confirm that the extension and reduction of the vegetation cover in Clipperton, mostly like on other atolls, are closely linked to two groups of factors. One group is related to weather and sea conditions, while the other is dependant from the fauna dynamics to be linked, positively or negatively, to human impacts.

The first and main factor, i.e., which has the fastest and strongest impact by being capable of destroying or burying in few hours the whole or part of the plant cover, is submerging waves loaded with sediments. In certain circumstances, they can cover the entire atoll ring. High waves of more than two meters are produced either by major hurricanes or by tsunamis. Since hurricanes are frequent in the region and may have a diameter of 500-1,000 kilometres, the fauna and flora are often directly impacted. For example, during a storm with strong swell and waves in April 2015, we observed fresh sand and gravel deposited by submerging waves in a strip several tens of meters long on the Eastern and Northern ring.

Another cause of vegetation changes is introduced plant or animal species and a demographic explosion of one or another community. Introduction of pigs was followed by the recovery of vegetation until their elimination in 1958 after which plant cover and diversity declined for forty years, followed by a new period of expansion until today. This last period is marked by the decline of the crab population but also the appearance of a new predator, the black rat Rattus rattus, accidently introduced with one of the two boat wreckages between 1997 and 2001. If the crab demographic decline can be explained by the lack of food after having eaten most of the plant cover, it is also partly linked to the rats which consume crabs and occupy their burrows.

The 2015 inventory has demonstrated that the atoll can be quickly recolonized by vegetation, from a few patches to almost half of the island in only 10 years. However, it will be important to monitor plant dynamics with the increasing presence of rats, known for their deleterious impacts on island native biota (Shiels et al., 2014), and more specifically to plant diversity and composition (Wolf et al. 2018).

\section{CONCLUSION}

Because of its geographical location, at the crossroad between the Pacific and American biogeographic regions, its extreme isolation, small size, particular geomorphology (with a closed lagoon), 
climate (on cyclone paths) and human history, the atoll of Clipperton (La Passion) is a unique natural laboratory of global scientific interest.

The observed changes in native and alien plant cover and species composition for the past three centuries are probably due to abiotic factors and natural disturbances (substrate, climate including cyclonic events) but also to biotic factors (native seabirds and crabs) and anthropogenic impacts, including the past introduction of pigs, rats and weeds. The vegetation dynamics seem to follow more or less 50year cycles tightly linked to human presence and activities. Thus, the alternating phases of plant abundance could be divided into a "pig phase" between 1897 and the 1950's with a high plant cover, followed by a "crab and seabird phase" between the 1960's and 2000 with a low plant cover, almost absent in 2001 and 2005, and the "rat phase" since 2005 with a new increase of the vegetation (Jost et al. 2015). These ecological cycles also demonstrate the resilience of the atoll ecosystem with the rapid recruitment of most of the vascular plants after natural and anthropogenic disturbances. However, the regular increase of coconut palms and the recent (accidental) introductions of alien species (e.g. the weeds Achyranthes aspera var. aspera and Salvia occidentalis) may profoundly alter the ecological balance of this small island ecosystem. Strict biosecurity measures should be set up during the future visits on the atoll, including scientific expeditions, to avoid new accidental plant and animal introductions.

Further research studies will include molecular analyses conducted on the native and alien plants and drift propagules, in order to construct phylogenies and assess the origin of all plant taxa found in the atoll (Pacific Islands versus Tropical America), as well as the assessment of the potential impacts of sea-level rise on the island biota. Long-term surveys will be necessary to confirm these ecological cycles, including plant dynamics, especially in the context of global changes.

\section{ACKNOWLEDGMENTS}

The "PASSION 2015" Expedition was made possible thanks to the French Navy, especially the crew of the Prairial Frigate, and the French Army (RIMaP-P), to the "Haut-commissariat de la République en Polynésie française", the "Agence française de développement (AFD)", the "Ministère des Outre-mer", the "Ministère des Affaires étrangères", the "Délégation française auprès de la Communauté du Pacifique", the University of French Polynesia, the "Institut du Droit économique de la Mer" in Monaco, and the NGO "Clipperton - Projets d'Outre-Mer (CPOM)".

\section{REFERENCES}

Belcher, E. 1843. Narrative of a Voyage Round the World Performed in Her Majesty's ship Sulphur during the years 1836-1842, including details of the Naval Operations in China from Dec. 1840 to Nov. 1841. London: Henri Colburn Publisher, Volume I.

Bouchard, J.-M. and Poupin, J. 2009. Eléments d'écologie et nouveau recensement de la population du crabe terrestre Gecarcinus planatus Stimpson, 1860 (Decapoda: Brachyoura). In: Clipperton, Environnement et Biodiversité d'un Microcosme Océanique, coord. L. Charpy, pp. 333-346. Paris: Publications scientifiques du Muséum, IRD Editions, Collection Patrimoines Naturels.

Boullet, V. Hivert, J. and Gigord, L. 2018. Un updated account on the vascular plants of the Iles Eparses (Southwest Indian Ocean). Atoll Research Bulletin 614: 1-64.

Braun-Blanquet, J. 1928. Pflanzensoziologie. Grundzüge der Vegetationskunde. Berlin: Biologische Studienbücher, 7.

Briot C. and Briot J. (ed) 2010. Journal de navigation du capitaine Michel Dubocage. Voyage à Amoy (Xiamen) par le Cap-Horn. Découverte de l'île de la Passion (1707-1716). Paris: Books on Demand.

Carlton, J. T. 1996. Biological invasions and cryptogenic species. Ecology, 77: 1653-1655. 
Charpy, L. (coord) 2009. Clipperton, Environnement et Biodiversité d'un Microcosme Océanique. Paris: Publications scientifiques du Muséum, IRD Editions, Collection Patrimoine Naturels.

Couté, A. and Garrouste, R. 2009. Un état des lieux de la flore et de la végétation terrestres et dulçaquicoles. In Clipperton, Environnement et Biodiversité d'un Microcosme Océanique, coord. L. Charpy, pp. 279-296. Paris : Publications scientifiques du Muséum, IRD Editions, Collection Patrimoines Naturels.

Ehrhardt, J.-P. 1968. Recensement en 1968 de la population de Geacarcinus planatus Stimpson sur l'îlot de Clipperton. Rapport 40. Paris: Centre de Recherches du Service de Santé des Armées, Division de Biologie Générale et Ecologie.

Ehrhardt, J.-P. 1971. Le comportement des Gecarcinidae brachyoures terrestres, d'après les exemplaires de l'île de Clipperton. In Actes du $96 e$ Congrès national des Sociétés Savantes, avril 1970, pp. 437452.

Ehrhardt, J.-P. and Niaussat, P.-M. 1970. Écologie et physiologie du brachyoure terrestre Gecarcinus planatus Stimpson (d'après les individus de l'atoll de Clipperton). Bull. Soc. Zool. France, 95(1): 41-54.

Johnston, I. M. 1931. The Flora of the Revillagigedo Islands. Proc. Cal. Acad. Sci. 20(2): 9-104.

Jost C.H. 1997. Rapport scientifique de l'expédition océanographique mexicano-française « SURPACLIP» à l'île de Clipperton, aux îles Revillagigedo et au Mexique du 16 nov. au 13 déc.1997. Rapport au Premier Ministre, au MAE, au SEOM. Paris: unpublished report.

Jost C.H. 2001. Rapport de l'expédition « Passion 2001 » à l'île de Clipperton du 17/02 au 06/03 2001. Rapport au Premier Ministre, au Secrétariat permanent auprès de la CPS, au MAE, au SEOM. 25/03/2001.

Jost, C.H. 2003. Clipperton - Ile de la Passion : une aire française du Pacifique à protéger! In: Les aires protégées insulaires et littorales tropicales, J.-M. Lebigre and P.-M. Decoudras (eds), p. 223-243. Pessac: CRET, Collection Iles et Archipels 32.

Jost, C.H. 2005a. Bibliographie de l'île de Clipperton, île de La Passion (1711-2005). Paris, Journal de la Société des Océanistes, 120-121: 181-197.

Jost C.H. 2005b. Risques environnementaux et enjeux à Clipperton (Pacifique français). Revue Européenne de Géographie CYBERGEO, 314.

Jost, C.H. 2011. Évolution, protection et gestion de l'environnement de Clipperton. Quels enjeux pour la France? In: "Dubocage de Bléville - Clipperton et la Chine", Actes du colloque du Havre pour le tricentenaire de la découverte française de Clipperton, 1-2 avril 2011, CHRH, Le Havre, $\mathrm{N}^{\circ}$ spécial hors-série, 163-222.

Jost, C.H. 2014. État des ressources génétiques forestières sur l'Île de La Passion (Clipperton). Une végétation en reconquête de l'atoll. In: Chapitre du Rapport de la FAO: «État des ressources génétiques forestières dans le monde », Tome 8 du Rapport de la France, pp 1-8, Paris: Ministère de l'agriculture. http://agriculture.gouv.fr/linventaire-national-des-ressources-genetiquesforestieres

Jost, C.H. and Andréfouët, S. 2006. Long term natural and human perturbations and current status of Clipperton Atoll, a remote island of the Eastern Pacific. Pacific Conservation Biology, 12(3): 207218.

Jost, C. H., Solis-Weiss V., Dumas P., Sanvicente Añorve L., Gravier-Bonnet N., Jost X., Grellier M, Lemus Santana E., Arakino M., Tchekemian, A.and Duchauchoy A. 2015. Rapport de l'expédition scientifique internationale PASSION 2015 à l'île de Clipperton, UPF, UNC, ULR, UNAM, AFD, MAEDI, MOM, novembre 2015. Papeete: unpublished report.

Le Coat De Kerveguen V. 1858. Acte de prise de possession de l'île de Clipperton par la France et Journal de bord.

Lorvelec, O. and Pascal, M. 2009. Les vertébrés de Clipperton soumis à un siècle et demi de bouleversements écologiques. In Clipperton, Environnement et Biodiversité d'un Microcosme Océanique, coord. L. Charpy, pp.393-412. Paris: Publications scientifiques du Muséum, IRD Editions, Collection Patrimoines Naturels. 
Meyer, J.-Y. 2013. Rapport de mission sur l'atoll de Maria (archipel des Australes) du 05 au 07 avril 2013 : inventaire floristique, observations ornithologiques et recommandations de gestion et de conservation. Délégation à la Recherche. Papeete: unpublished report.

Morrell, B. 1832. A narrative of four voyages to the South Sea, North and South Pacific Ocean, Chinese Sea, Ethiopic and Southern Atlantic Ocean, Indian and Antarctic Ocean from the year 1822 to 1831. New-York: J. \& J. Harper.

Mueller-Dombois, D. and Fosberg, F.R. 1998. Vegetation of the Tropical Pacific Islands. New-York: Springer.

Niaussat, P.-M., and Ehrhardt, J.P. 1971. Quelques aspects de l'éthologie du crabe terrestre Gecarcinus planatus Stimpson de l'atoll de Clipperton. In: Vie et milieu, IIIe Symposium Européen de Biologie Marine, Arcachon, 22, pp. 167-191.

Niaussat, P.-M. 1986. Le Lagon et l'Atoll de Clipperton. Paris: Académie des Sciences d'Outre-Mer, Institut du Pacifique.

Niva, P. and Taputuarai, R. 2013. Inventaire archéologique et botanique de l'atoll de Tairao, archipel des Tuamotu. Papeete: unpublished report.

Pease W. H. 1868. On the existence of an atoll near the West coast of America, and proof of its elevation. Pp 199-201 in Proceedings of the California Academy of Natural Sciences, Harvard College Library, Volume III.

Sachet, M.-H. 1959. Vegetation of Clipperton island. In: Proceedings of the IX International Botanical Congress, August 19-29, 1959, Montreal, pp 337-338. Ottawa: Runge Press, Toronto: University of Toronto Press.

Sachet, M.-H. 1962. Geography and land ecology of Clipperton island. Atoll Research Bulletin, 86: 1-115.

Shiels, A. B., Pitt, W. C., Sugihara, R. T. and Witmer, G. W. 2014. Biology and impacts of Pacific Island invasive species. 11. Rattus rattus, the black rat (Rodentia: Muridae), Pacific Science 68(2): 145184.

Taylor W.R. 1939. Algae collected on the Presidential cruise of 1938. Smiths. Misc. Coll. 98, 9, pp. 1-58.

Taxit, R.-G.-E. and Ehrhardt, J.-P. 1981. Précarité de l'écosystème lagonaire de Clipperton. Revue International d'Océanographie médicale 63-64: 49-63.

Terrier, M. 1912. Rapport du Lieutenant de vaisseau Terrier à Monsieur le Capitaine de Vaisseau, Commandant du Duguay-Trouin, Chef de la Division Navale de l'Océan Pacifique, le 30 novembre 1897. In Mémoire défensif présenté par le Gouvernement de la France dans l'Affaire de l'île Clipperton, pp. 338-343.

Weimerskirch H., Le Corre M., Bost C.A., Ballance L. and Pitman R. 2009. L'avifaune de l'île Clipperton et l'écologie des oiseaux marins. In: Clipperton, Environnement et Biodiversité d'un Microcosme Océanique, coord. L. Charpy, pp. 381-392. Paris: Publications scientifiques du Muséum, IRD Editions, Collection Patrimoines Naturels.

Wolf C., Young H.S., Zilliacus, K.M., Wegmann A.S., McKown M., Holmes, N.D., Tershy B.R., Dirzo R., Kropidlowski S. and Croll D.A. 2018. Invasive rats eradication strongly impacts plant recruitment on a tropical atoll. PLoS ONE 13(7): e0200743. 
Table 1. Past description of the vegetation of Clipperton (La Passion) atoll and its evolution between the $18^{\text {th }}$ and $20^{\text {th }}$ centuries.

\begin{tabular}{|c|c|c|c|}
\hline $\begin{array}{c}\text { Period or } \\
\text { year of } \\
\text { observation }\end{array}$ & Author & Description & $\begin{array}{l}\text { Documents } \\
\text { (Reference) }\end{array}$ \\
\hline 1711 & $\begin{array}{l}\text { French discoverer } \\
\text { Michel Dubocage }\end{array}$ & $\begin{array}{l}\text { "Some brushwood and one dry tree on the } \\
\text { Northeast point [...] The Western side } \\
\text { appeared to us with few small bushes" }\end{array}$ & $\begin{array}{l}\text { Sketch of the } \\
\text { island } \\
\text { (Dubocage, } \\
\text { 1711) }\end{array}$ \\
\hline 1825 & $\begin{array}{l}\text { American Captain } \\
\text { Benjamin Morrell }\end{array}$ & $\begin{array}{l}\text { "Little shrubbery and some coarse grass, } \\
\text { among which, I think, fresh water might be } \\
\text { found by digging. Among the few plant } \\
\text { productions of this island, we found a plant } \\
\text { resembling sarsaparilla", which badly poisoned } \\
\text { several of the crew who handled it" }\end{array}$ & (Morell, 1832) \\
\hline 1839 & $\begin{array}{l}\text { British Admiral Sir } \\
\text { Edward Belcher }\end{array}$ & $\begin{array}{l}\text { "Very-dangerous low lagoon island, destitute } \\
\text { of trees; North: appears to be clothed with } \\
\text { something like grass" }\end{array}$ & $\begin{array}{l}\text { Map (Belcher } \\
\text { 1843) }\end{array}$ \\
\hline 1858 & $\begin{array}{l}\text { French Lieutenant } \\
\text { Le Coat de } \\
\text { Kerveguen }\end{array}$ & $\begin{array}{l}\text { "The land is only covered with guano. The } \\
\text { lagoon is totally closed and its water is salted» }\end{array}$ & $\begin{array}{l}\text { Map (Le Coat } \\
\text { de Kerveguen, } \\
1858)\end{array}$ \\
\hline 1861 & $\begin{array}{l}\text { American } \\
\text { Lieutenant } \\
\text { Griswold }\end{array}$ & $\begin{array}{l}\text { "I did not find the least sign of plant life upon } \\
\text { the island. The only plant seen grew in } \\
\text { considerable quantities in the lagoon" }\end{array}$ & $\begin{array}{l}\text { (cited in Pease, } \\
1868 \text { ) }\end{array}$ \\
\hline 1897 & $\begin{array}{l}\text { French Lieutenant } \\
\text { Terrier } \\
\end{array}$ & $\begin{array}{l}\text { "There is no vegetation on the island apart } \\
\text { from two young coconut trees grown in crates" }\end{array}$ & (Terrier, 1897) \\
\hline 1934 & $\begin{array}{l}\text { French Navy vessel } \\
\text { "Jeanne d'Arc" }\end{array}$ & $\begin{array}{l}\text { Vegetation was described as "covering a big } \\
\text { part of the land" }\end{array}$ & $\begin{array}{l}\text { Map, pictures } \\
\text { and aerial } \\
\text { photos (Report, } \\
1935 \text { ) }\end{array}$ \\
\hline 1938 & $\begin{array}{l}\text { "US President } \\
\text { Roosevelt" cruise }\end{array}$ & Important vegetation cover on photographs & $\begin{array}{l}\text { Aerial photos } \\
\text { (Taylor, 1939) } \\
\end{array}$ \\
\hline 1958 & $\begin{array}{l}\text { French botanist M.- } \\
\text { H. Sachet }\end{array}$ & $\begin{array}{l}\text { Abundant low vegetation covering almost } 80 \% \\
\text { of the land }\end{array}$ & $\begin{array}{l}\text { Map (Sachet, } \\
\text { 1962) }\end{array}$ \\
\hline 1968 & $\begin{array}{l}\text { French « Missions } \\
\text { Bougainville » }\end{array}$ & Vegetation cover decrease on map & $\begin{array}{l}\text { Map (Ehrhardt } \\
\text { and Niaussat, } \\
\text { 1970) } \\
\end{array}$ \\
\hline 1980 & $\begin{array}{l}\text { French Cdt J.-Y. } \\
\text { Cousteau }\end{array}$ & $\begin{array}{l}\text { Vegetation continues to decline to scarce } \\
\text { patches }\end{array}$ & Map and movie \\
\hline 1997 & $\begin{array}{l}\text { French geographer } \\
\text { C. Jost } \\
\end{array}$ & $\begin{array}{l}\text { Vegetation totally absent of the coral rim, } \\
\text { except } 674 \text { coconut trees }\end{array}$ & $\begin{array}{l}\text { Map (Jost, } \\
\text { 1997) }\end{array}$ \\
\hline 2005 & $\begin{array}{l}\text { French explorer J.- } \\
\text { L. Etienne }\end{array}$ & $\begin{array}{l}\text { Patches of herbaceous and subshrub vegetation } \\
\text { in a few restricted zones }\end{array}$ & $\begin{array}{l}\text { Map (Couté and } \\
\text { Garrouste } \\
\text { 2009) }\end{array}$ \\
\hline
\end{tabular}

${ }^{7}$ Refers to a creeping vine of the genus Smilax (Smilacaceae), more probably Ipomoea pes-caprae 
Table 2. List of the 15 terrestrial vascular plant species observed in 2015 on Clipperton (La Passion) atoll with their biological characteristics and proposed biogeographical and naturalization status.

\begin{tabular}{|c|c|c|c|c|c|c|c|}
\hline Family & Scientific name & $\begin{array}{l}\text { Life } \\
\text { form }\end{array}$ & $\begin{array}{l}\text { Dispersal } \\
\text { mode }\end{array}$ & $\begin{array}{l}\text { Native } \\
\text { range }\end{array}$ & $\begin{array}{l}\text { First } \\
\text { obs. }\end{array}$ & $\begin{array}{l}\text { Biogeogra- } \\
\text { phical status }\end{array}$ & $\begin{array}{l}\text { Naturalization } \\
\text { status }\end{array}$ \\
\hline \multicolumn{8}{|c|}{ MONOCOTYLEDONS } \\
\hline $\begin{array}{l}\text { Arecaceae } \\
\text { (Palmae) }\end{array}$ & Cocos nucifera L. & $\begin{array}{l}\text { tree } \\
\text { (palm) }\end{array}$ & hydrochory & & 1897 & $\begin{array}{l}\text { introduced } \\
\text { (intentional) }\end{array}$ & $\begin{array}{l}\text { cultivated, } \\
\text { naturalized }\end{array}$ \\
\hline \multirow[t]{2}{*}{ Cyperaceae } & $\begin{array}{l}\text { Eleocharis } \\
\text { geniculata }(\mathrm{L} .) \\
\text { Roem. \& Schult. }\end{array}$ & $\begin{array}{l}\text { erect herb } \\
\text { (sedge) }\end{array}$ & $\begin{array}{l}\text { epizoochory or } \\
\text { endozoochory }\end{array}$ & $\begin{array}{l}\text { Caribbean, } \\
\text { South } \\
\text { America, } \\
\text { Western } \\
\text { Polynesia }\end{array}$ & 1897 & native & naturalized \\
\hline & $\begin{array}{l}\text { Eleocharis mutata } \\
\text { (L.) Roem. \& } \\
\text { Schult. }\end{array}$ & $\begin{array}{l}\text { erect herb } \\
\text { (sedge) }\end{array}$ & $\begin{array}{l}\text { epizoochory or } \\
\text { endozoochory }\end{array}$ & $\begin{array}{l}\text { Caribbean, } \\
\text { South } \\
\text { America }\end{array}$ & 1897 & native & naturalized \\
\hline \multirow[t]{2}{*}{$\begin{array}{l}\text { Poaceae } \\
\text { (Graminae) }\end{array}$} & $\begin{array}{l}\text { Cenchrus } \\
\text { echinatus L. }\end{array}$ & $\begin{array}{l}\text { erect herb } \\
\text { (grass) }\end{array}$ & epizoochory & $\begin{array}{l}\text { Caribbean, } \\
\text { South } \\
\text { America }\end{array}$ & 1958 & $\begin{array}{l}\text { introduced } \\
\text { (accidental) }\end{array}$ & «weed» \\
\hline & $\begin{array}{l}\text { Eragrostis ciliaris } \\
\text { (L.) R.Br. }\end{array}$ & $\begin{array}{l}\text { erect herb } \\
\text { (grass) }\end{array}$ & endozoochory & Caribbean & 1958 & $\begin{array}{l}\text { introduced } \\
\text { (accidental) }\end{array}$ & «weed » \\
\hline \multicolumn{8}{|c|}{ DICOTYLEDONS } \\
\hline Amaranthaceae & $\begin{array}{l}\text { Achyranthes } \\
\text { aspera var. aspera } \\
\text { L. }\end{array}$ & $\begin{array}{l}\text { erect } \\
\text { (woody) } \\
\text { herb }\end{array}$ & epizoochory & Asia & 2015 & $\begin{array}{l}\text { introduced } \\
\text { (accidental) }\end{array}$ & «weed» \\
\hline Boraginaceae & $\begin{array}{l}\text { Heliotropium } \\
\text { curassavicum L. }\end{array}$ & $\begin{array}{l}\text { erect } \\
\text { (woody) } \\
\text { herb }\end{array}$ & $\begin{array}{l}\text { hydrochory, } \\
\text { endozoochory }\end{array}$ & $\begin{array}{l}\text { Caribbean, } \\
\text { South } \\
\text { America, } \\
\text { Australia, } \\
\text { Hawaii }\end{array}$ & 1958 & native & naturalized \\
\hline \multirow[t]{2}{*}{ Convolvulaceae } & $\begin{array}{l}\text { Ipomoea pes- } \\
\text { caprae subsp. } \\
\text { brasiliensis (L.) } \\
\text { Ooststr. }\end{array}$ & $\begin{array}{l}\text { creeping } \\
\text { vine }\end{array}$ & hydrochory & Pantropical & 1897 & native & naturalized \\
\hline & Ipomoea triloba $\mathrm{L}$. & $\begin{array}{l}\text { creeping } \\
\text { vine }\end{array}$ & hydrochory & $\begin{array}{l}\text { Caribbean, } \\
\text { South } \\
\text { America }\end{array}$ & 1897 & $\begin{array}{l}\text { introduced } \\
\text { (accidental)? }\end{array}$ & naturalized \\
\hline Lamiaceae & $\begin{array}{l}\text { Salvia occidentalis } \\
\text { Sw. }\end{array}$ & sub-shrub & epizoochory & Caribbean & 2015 & $\begin{array}{l}\text { introduced } \\
\text { (accidental) }\end{array}$ & « weed $»$ \\
\hline \multirow[t]{2}{*}{ Malvaceae } & $\begin{array}{l}\text { Corchorus } \\
\text { aestuans } \mathrm{L} .\end{array}$ & erect herb & anemochory & Caribbean & 1958 & $\begin{array}{l}\text { introduced } \\
\text { (accidental)? }\end{array}$ & « weed » \\
\hline & $\begin{array}{l}\text { Sida rhombifolia } \\
\text { L. }\end{array}$ & sub-shrub & epizoochory & $\begin{array}{l}\text { Caribbean, } \\
\text { South } \\
\text { America }\end{array}$ & 1958 & $\begin{array}{l}\text { introduced } \\
\text { (accidental)? }\end{array}$ & «weed » \\
\hline Phyllanthaceae & $\begin{array}{l}\text { Phyllanthus } \\
\text { amarus } \\
\text { Schumach. \& } \\
\text { Tonn. }\end{array}$ & erect herb & endozoochory & Caribbean & 1958 & $\begin{array}{l}\text { introduced } \\
\text { (accidental)? }\end{array}$ & «weed » \\
\hline Portulacaceae & $\begin{array}{l}\text { Portulaca } \\
\text { oleracea L. }\end{array}$ & $\begin{array}{l}\text { prostrate } \\
\text { herb }\end{array}$ & $\begin{array}{l}\text { anemochory, } \\
\text { epizoochory }\end{array}$ & Caribbean & 1958 & $\begin{array}{l}\text { introduced } \\
\text { (accidental)? }\end{array}$ & «weed » \\
\hline Solanaceae & $\begin{array}{l}\text { Nicotiana glauca } \\
\text { Graham }\end{array}$ & sub-shrub & $\begin{array}{l}\text { endozoochory, } \\
\text { epizoochory }\end{array}$ & $\begin{array}{l}\text { South } \\
\text { America }\end{array}$ & 1905 & $\begin{array}{l}\text { introduced } \\
\text { (intentional) } \\
\end{array}$ & «weed » \\
\hline
\end{tabular}


Table 3. Changes in plant species composition on Clipperton (La Passion) atoll.

\begin{tabular}{|c|c|c|c|c|c|c|}
\hline Family & Scientific name & Life form & Status & 1958 & 2005 & 2015 \\
\hline Amaranthaceae & Achyranthes aspera var. aspera L. & herb & introduced & & & $\mathrm{X}$ \\
\hline $\begin{array}{l}\text { Arecaceae } \\
(\text { Palmae })\end{array}$ & Cocos nucifera L. & tree & introduced & $\mathrm{X}$ & $\mathrm{X}$ & $\mathrm{X}$ \\
\hline \multirow[t]{2}{*}{$\begin{array}{l}\text { Asteraceae } \\
(\text { Compositae })\end{array}$} & $\begin{array}{l}\text { Erigeron bonariensis L. (syn. Conyza } \\
\text { bonariensis) }\end{array}$ & herb & introduced & $\mathrm{X}$ & & \\
\hline & $\begin{array}{l}\text { Eclipta prostata }(\mathrm{L} .) \mathrm{L} . \\
\text { (syn. Eclipta alba) }\end{array}$ & herb & introduced & $\mathrm{X}$ & & \\
\hline Boraginaceae & Heliotropium curassavicum L. & erect herb & native & $\mathrm{X}$ & $\mathrm{X}$ & $\mathrm{X}$ \\
\hline Brassicaceae & Brassica juncea (L.) Czern. & herb & introduced & $\mathrm{X}$ & & \\
\hline \multirow[t]{2}{*}{ Convolvulaceae } & $\begin{array}{l}\text { Ipomoea pes-caprae subsp. brasiliensis (L.) } \\
\text { Ooststr. }\end{array}$ & $\begin{array}{l}\text { creeping } \\
\text { vine }\end{array}$ & native & $\mathrm{X}$ & $\mathrm{X}$ & $\mathrm{X}$ \\
\hline & Ipomoea triloba $\mathrm{L}$. & $\begin{array}{l}\text { creeping } \\
\text { vine }\end{array}$ & introduced & $\mathrm{X}$ & $\mathrm{X}$ & $\mathrm{X}$ \\
\hline \multirow[t]{4}{*}{ Cyperaceae } & Eleocharis geniculata (L.) Roem. \& Schult. & sedge & native & $\mathrm{X}$ & $\mathrm{X}$ & $\mathrm{X}$ \\
\hline & Eleocharis mutata (L.) Roem. \& Schult. & sedge & native & $\mathrm{X}$ & $\mathrm{X}$ & $\mathrm{X}$ \\
\hline & $\begin{array}{l}\text { Cyperus subsquarrosus (Muhl.) Bauters } \\
\text { (syn. Hemicarpha micrantha) }\end{array}$ & sedge & native & $\mathrm{X}$ & & \\
\hline & $\begin{array}{l}\text { Schoenoplectus acutus var. occidentalis } \\
\text { (Muhl. Ex Bigelow) A.Löve \& D.Löve (syn. } \\
\text { Scirpus rubiginosus) }\end{array}$ & sedge & native & $\mathrm{X}$ & & \\
\hline \multirow{4}{*}{$\begin{array}{l}\text { Fabaceae } \\
\text { (Leguminosae) }\end{array}$} & Caesalpinia sp. & shrub & native & $\mathrm{X}$ & & \\
\hline & Canavalia cf. rosea (Sw.) DC. & vine & native & $\mathrm{X}$ & $\mathrm{X}$ & \\
\hline & Mucuna sloanei Fawc. \& Rendle & liana & native & $\mathrm{X}$ & & $\begin{array}{l}\text { (drift } \\
\text { seed) }\end{array}$ \\
\hline & $\begin{array}{l}\text { Leptospron adenanthum (G.Mey.) } \\
\text { A.Delgado (syn. Phaseolus adenanthus) }\end{array}$ & creeper & introduced & $\mathrm{X}$ & & \\
\hline Lamiaceae & Salvia occidentalis Sw. & shrub & introduced & & & $\mathrm{X}$ \\
\hline \multirow[t]{4}{*}{ Malvaceae } & Corchorus aestuans L. & erect herb & introduced & $\mathrm{X}$ & $\mathrm{X}$ & $\mathrm{X}$ \\
\hline & Hibiscus tiliaceus $\mathrm{L}$. & tree & introduced & & $\mathrm{X}$ & \\
\hline & Sida rhombifolia L. & shrub & introduced & $\mathrm{X}$ & $\mathrm{X}$ & $\mathrm{X}$ \\
\hline & Waltheria indica $\mathrm{L}$. & erect herb & introduced & $\mathrm{X}$ & & \\
\hline Phyllanthaceae & Phyllanthus amarus Schumach. \& Thonn. & herb & introduced & $\mathrm{X}$ & & $\mathrm{X}$ \\
\hline \multirow{4}{*}{$\begin{array}{l}\text { Poaceae } \\
\text { (Gramineae) }\end{array}$} & Cenchrus echinatus L. & grass & introduced & $\mathrm{X}$ & & $\mathrm{X}$ \\
\hline & Dactyloctenium aegyptium (L.) Willd. & grass & introduced & $\mathrm{X}$ & & \\
\hline & $\begin{array}{l}\text { Eragrostis amabilis (L.) Wight \& Arn. ex } \\
\text { Nees }\end{array}$ & grass & introduced & $\mathrm{X}$ & & \\
\hline & Eragrostis ciliaris (L.) R.Br. & grass & introduced & $\mathrm{X}$ & & $\mathrm{X} ?$ \\
\hline Portulacaceae & Portulaca oleracea L. & $\begin{array}{l}\text { prostrate } \\
\text { herb }\end{array}$ & introduced & $\mathrm{X}$ & $\mathrm{X}$ & $\mathrm{X}$ \\
\hline Sapindaceae & Sapindus saponaria L. & tree & native & $\mathrm{X}$ & & \\
\hline \multirow[t]{2}{*}{ Solanaceae } & Nicotiana glauca Graham & shrub & introduced & $\mathrm{X}$ & & $\mathrm{X}$ \\
\hline & $\begin{array}{l}\text { Solanum americanum Mill. } \\
\text { (syn. Solanum nigrum var. americanum) }\end{array}$ & herb & introduced & $\mathrm{X}$ & & \\
\hline TOTAL & & & & 27 & 11 & 15 \\
\hline
\end{tabular}


Table 4. Evolution in species richness on Clipperton (La Passion) atoll.

\begin{tabular}{|l|l|l|l|}
\hline Year & $\mathbf{1 9 5 8}$ & $\mathbf{2 0 0 5}$ & $\mathbf{2 0 1 5}$ \\
\hline Total number of species & 27 & 11 & 15 \\
\hline Number of introduced species & 20 & 6 & 11 \\
\hline Number of native species & 7 & 5 & 4 \\
\hline Newly discovered species since 1958 & - & 1 & 2 \\
\hline Number of species not found in-between each scientific expedition & - & 17 & 0 \\
\hline Number of species not found since 1958 & - & 17 & 14 \\
\hline
\end{tabular}

Table 5. Evolution in the number of living coconut palms on Clipperton (La Passion) atoll.

\begin{tabular}{|c|c|c|c|c|c|c|c|c|}
\hline Year & 1897 & 1934 & 1958 & 1997 & 2001 & 2005 & 2013 & 2015 \\
\hline Size & & & & $>1 \mathrm{~m}$ & $>1 \mathrm{~m}$ & $>1.50 \mathrm{~m}$ & $>1 \mathrm{~m}$ & $>1 \mathrm{~m}$ \\
\hline Number & 2 & 40 & 353 & 557 & 674 & 581 & 806 & 847 \\
\hline Size & & & & & & $<1.50 \mathrm{~m}$ & & $<1 \mathrm{~m}$ \\
\hline Number & & & & & & 3083 & & 1395 \\
\hline
\end{tabular}




\begin{abstract}
APPENDIX
Photographs of some particular plant species and vegetation zones (credit: Xénia JOST).

Photo A. Small patch of the recently introduced weed Salvia occidentalis (inside the red circle) within a dense stand of Sida rhombifolia
\end{abstract}

Photo B. Dense coconut palms grove in "Bois de Bougainville" with almost no plant undergrowth

Photo C. Tree tobacco Nicotiana glauca, a subshrub first observed in 1958 and rediscovered in 2015

Photo D. A view of dense stands of the creeping vine Ipomoea pes-caprae (on the right: South side) and the introduced I. triloba (on the left: North side) from "Le Rocher"

Photo E. Dense stand of Ipomoea triloba with the lagoon visible on the right side

Photo F. Dense stand of the native tufted sedge Eleocharis mutata near "Le Crochet"

Photo G. A view of the "Bois de Bougainville" area with a dense stand of Ipomoea triloba in the foreground and coconut groves in the background

Photo H. A view of the "Pince Nord" area with the "Stèle" on a tumulus in the right background, and dense stand of Ipomoea triloba with a patch of Eleocharis mutata on the foreground

Photo I. A view of the Eastern coast with an expanding pure stand of Ipomoea triloba surounding boobies nesting sites

Photo J. A view between the 3rd coconut grove and "Le Rocher" in the background (southward): Ipomoea pes-caprae on the left foreground and patches of Eleocharis geniculata elsewhere 


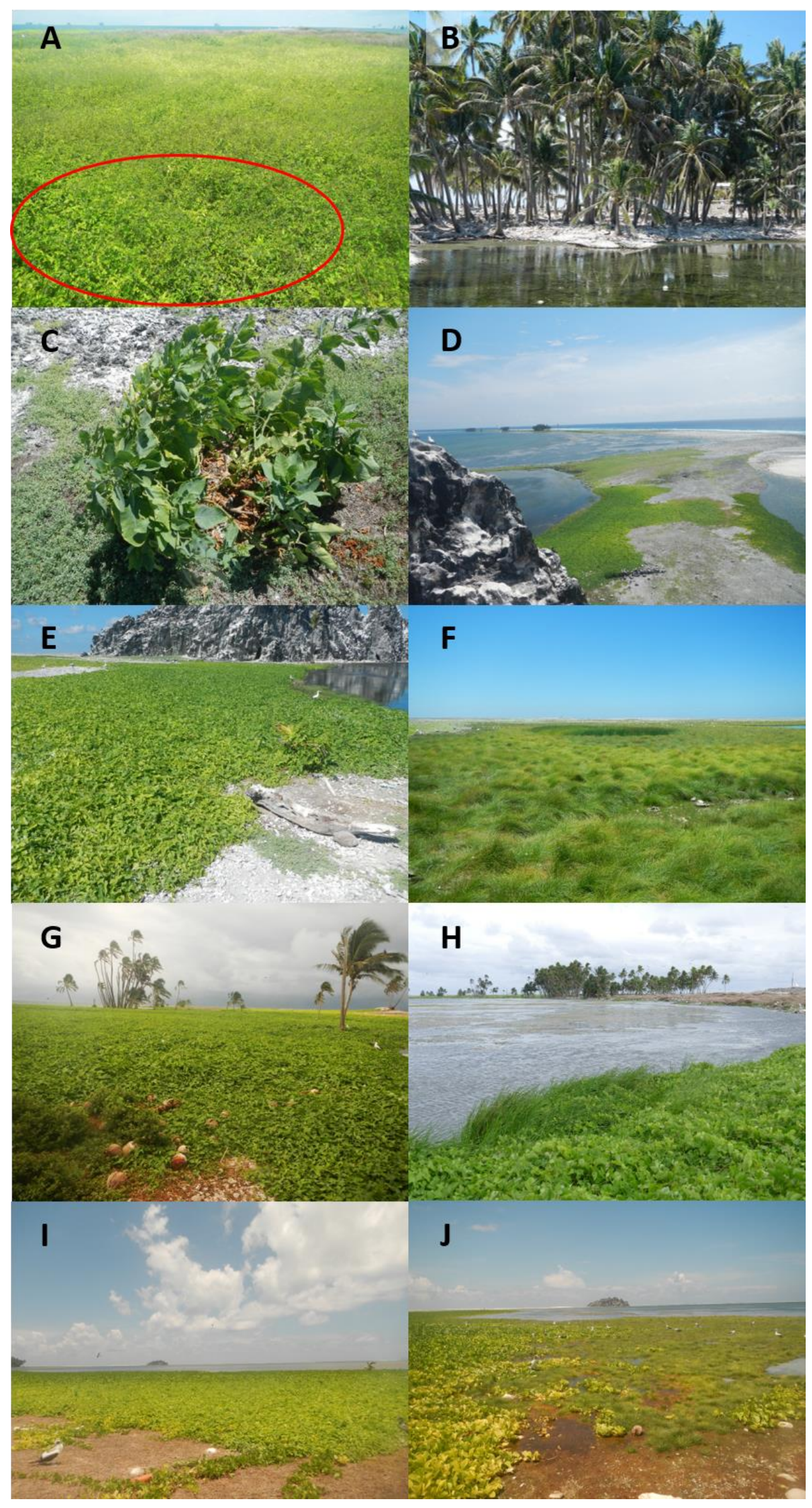

